Prepared in cooperation with U.S. Marine Corps, Quantico, Virginia

\title{
Quality of Water and Bottom Material in Breckenridge Reservoir, Virginia, September 2008 through August 2009
}

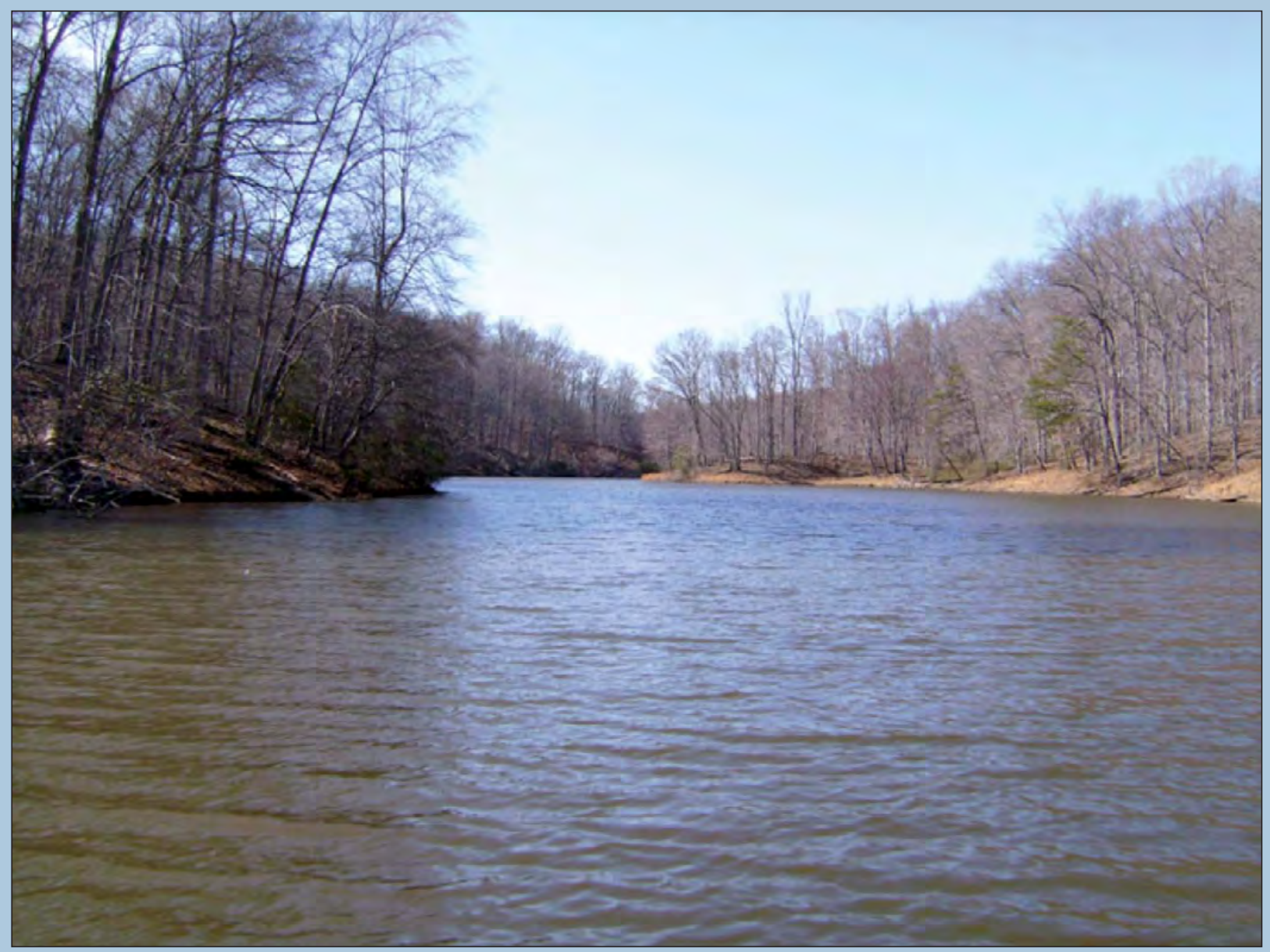

Open-File Report 2011-1305 
Cover photograph. Breckenridge Reservoir, Quantico, Virginia. 


\section{Quality of Water and Bottom Material in Breckenridge Reservoir, Virginia, September 2008 through August 2009}

By R. Russell Lotspeich

Prepared in cooperation with U.S. Marine Corps, Quantico, Virginia

Open-File Report 2011-1305

U.S. Department of the Interior

U.S. Geological Survey 


\title{
U.S. Department of the Interior \\ KEN SALAZAR, Secretary \\ U.S. Geological Survey \\ Marcia K. McNutt, Director
}

\author{
U.S. Geological Survey, Reston, Virginia: 2012
}

For more information on the USGS - the Federal source for science about the Earth, its natural and living resources, natural hazards, and the environment, visit http://Www.usgs.gov or call 1-888-ASK-USGS.

For an overview of USGS information products, including maps, imagery, and publications, visit $h t t p: / / w w w . u s g s . g o v / p u b p r o d$

To order this and other USGS information products, visit http://store.usgs.gov

Any use of trade, product, or firm names is for descriptive purposes only and does not imply endorsement by the U.S. Government.

Although this report is in the public domain, permission must be secured from the individual copyright owners to reproduce any copyrighted materials contained within this report.

Suggested citation:

Lotspeich, R.R., 2012, Quality of water and bottom material in Breckenridge Reservoir, Virginia, September 2008 through August 2009: U.S. Geological Survey Open-File Report 2011-1305, 19 p., plus appendixes. 


\section{Contents}

Abstract Introduction
Purpose and Scope
Description of Study Area
Historical Streamflow and Climatological Data in the Study Area
Sample Collection and Analysis
$\quad$ Sater Quality of Reservoir Sites
$\quad$ Physical Properties
$\quad$ Water Temperature
$\quad$ Water Clarity

\section{Figures}

1-2. Maps showing:

1. Location of study area, reference locations, and streamflow and climatological sites near Breckenridge Reservoir, Virginia..

2. Breckenridge Reservoir, Virginia, watershed, tributary streams, and sampling sites.

3. Graph showing mean monthly discharge in water year 2009 and minimum, maximum, and mean monthly discharges for the period of record at North Branch, Middle Branch, and South Branch Chopawamsic Creeks near Breckenridge Reservoir, Virginia

4. Map showing location of sampling sites and cross-section profiling points in Breckenridge Reservoir, Virginia 
5-10. Graphs showing depth-averaged seasonal:

5. Water temperature for Breckenridge Reservoir, Virginia, September 2008 through August 2009

6. Dissolved oxygen for Breckenridge Reservoir, Virginia, September 2008 through August 2009

7. Specific conductance for Breckenridge Reservoir, Virginia, September 2008 through August 2009

8. $\mathrm{pH}$ for Breckenridge Reservoir, Virginia, September 2008 through August 2009

9. Turbidity for Breckenridge Reservoir, Virginia, September 2008

through August 2009

10. Graph showing monthly mean E. coli counts, turbidity measurements, and Secchi-disk depths, and cumulative mean daily discharges in tributary streams

for sampling periods in Breckenridge Reservoir, Virginia .

\section{Tables}

1. Physical characteristics of Breckenridge, Lunga, Pea Hill Arm of Lake Gaston, Chickahominy, Diascund Creek, and Little Creek Reservoirs, Virginia

2. Watershed land use for Breckenridge Reservoir, Virginia ...

3. Data collection and reference sites, Breckenridge Reservoir, Virginia, September 2008 through August 2009.

4. Summary of physical properties at 1-foot depth for sampling sites in Breckenridge Reservoir and tributaries, Virginia, September 2008 through August 2009.

5. Nutrient concentrations at various depths at sampling sites, Breckenridge Reservoir, Virginia, December 2008 and August 2009.

6. Mean dissolved major-ion concentrations at 1-foot depth at sampling sites, in Breckenridge Reservoir, Virginia, during September 2008 through August 2009, compared to other reservoirs 13

7. Dissolved major-ion concentrations at various depths at sampling sites, in Breckenridge Reservoir, Virginia, December 17, 2008, and August 25, 2009 13

8. Concentrations of trace elements in bottom-material samples from Breckenridge Reservoir, Virginia, July 7, 2009

9. Mean trace-element concentrations in bottom material from Breckenridge and Lunga Reservoirs, Virginia 


\section{Conversion Factors}

Inch/Pound to SI

\begin{tabular}{lcl}
\hline \multicolumn{1}{c}{ Multiply } & By & \multicolumn{1}{c}{ To obtain } \\
\hline inch (in.) & Length & \\
foot (ft) & 2.54 & centimeter $(\mathrm{cm})$ \\
mile (mi) & 0.3048 & meter $(\mathrm{m})$ \\
& 1.609 & kilometer $(\mathrm{km})$ \\
\hline acre & Area & \\
acre & 0.0015625 & square mile $\left(\mathrm{m}^{2}\right)$ \\
acre &, 047 & square meter $\left(\mathrm{m}^{2}\right)$ \\
\hline & 0.004047 & square kilometer $\left(\mathrm{km}^{2}\right)$ \\
\hline gallon (gal) & Volume & \\
gallon (gal) & 3.785 & liter $(\mathrm{L})$ \\
million gallons $(\mathrm{Mgal})$ & 0.003785 & cubic meter $\left(\mathrm{m}^{3}\right)$ \\
\hline & 3,785 & cubic meter $\left(\mathrm{m}^{3}\right)$ \\
\hline cubic foot per second $\left(\mathrm{ft}{ }^{3} / \mathrm{s}\right)$ & Flow rate & \\
million gallons per day $(\mathrm{Mgal} / \mathrm{d})$ & 0.02832 & cubic meter per second $\left(\mathrm{m}^{3} / \mathrm{s}\right)$ \\
inch per year (in/yr) & 0.04381 & cubic meter per second $\left(\mathrm{m}^{3} / \mathrm{s}\right)$ \\
& 25.4 & millimeter per year $(\mathrm{mm} / \mathrm{yr})$ \\
\hline
\end{tabular}

Temperature in degrees Fahrenheit $\left({ }^{\circ} \mathrm{F}\right)$ may be converted to degrees Celsius $\left({ }^{\circ} \mathrm{C}\right)$ as follows: ${ }^{\circ} \mathrm{C}=\left({ }^{\circ} \mathrm{F}-32\right) / 1.8$.

Horizontal coordinate information (latitude-longitude) is referenced to the North American Datum of 1983 (NAD 83).

Vertical elevation information is referenced to North American Vertical Datum of 1988 (NAVD 88).

Specific conductance is given in microsiemens per centimeter at 25 degrees Celsius $\left(\mu \mathrm{S} / \mathrm{cm}\right.$ at $\left.25^{\circ} \mathrm{C}\right)$.

Concentrations of chemical constituents in water are given either in milligrams per liter $(\mathrm{mg} / \mathrm{L})$ or micrograms per liter $(\mu \mathrm{g} / \mathrm{L})$.

Concentrations of chemical constituents in sediment are given either in micrograms per gram $(\mu \mathrm{g} / \mathrm{g})$ or micrograms per kilogram $(\mu \mathrm{g} / \mathrm{kg})$.

\section{Water quality, soil-gas, and soil units}

$\mathrm{L}$

$\mu \mathrm{g} \quad$ microgram

$\mu \mathrm{g} / \mathrm{g} \quad$ microgram per gram

$\mu \mathrm{g} / \mathrm{L} \quad$ microgram per liter

$\mu \mathrm{g} / \mathrm{kg} \quad$ microgram per kilogram

$\mu / \mathrm{m} \quad$ micrometer

$\mu \mathrm{S} / \mathrm{cm} \quad$ microsiemens per centimeter

$\mathrm{mg} / \mathrm{L} \quad$ milligrams per liter

$\mathrm{mL} \quad$ milliliter

$\mathrm{mm} \quad$ millimeter 


\section{Selected acronyms and abbreviations used in this report:}

$\begin{array}{ll}\text { DEO } & \text { Virginia Department of Environmental Quality } \\ \text { DOC } & \text { dissolved organic carbon } \\ \text { FNU } & \text { formazin nephelometric units } \\ > & \text { greater than } \\ < & \text { less than } \\ \text { L } & \text { liter } \\ \text { MRL } & \text { minimum reporting level } \\ \text { NOAA } & \text { National Oceanic and Atmospheric Administration } \\ \text { NWIS } & \text { National Water Information System } \\ \text { NWOL } & \text { National Water Quality Laboratory } \\ \text { N } & \text { normality } \\ \text { ppb } & \text { parts per billion } \\ \text { SWCB } & \text { Virginia State Water Control Board } \\ \text { TSI } & \text { trophic state index } \\ \text { TSIP } & \text { trophic state index based on total phosphorus concentrations } \\ \text { TOC } & \text { total organic carbon } \\ \text { USGS } & \text { U.S. Geological Survey } \\ \text { USMC } & \text { U.S. Marine Corps }\end{array}$




\title{
Quality of Water and Bottom Material in Breckenridge Reservoir, Virginia, September 2008 through August 2009
}

\author{
By R. Russel Lotspeich
}

\begin{abstract}
Breckenridge Reservoir is located within the U.S. Marine Corps Base in Quantico, which is in the Potomac River basin and the Piedmont Physiographic Province of northern Virginia. Because it serves as the principal water supply for the U.S. Marine Corps Base in Quantico, an assessment of the water-quality of Breckenridge Reservoir was initiated.

Water samples were collected and physical properties were measured by the U.S. Geological Survey at three sites in Breckenridge Reservoir, and physical properties were measured at six additional reservoir sites from September 2008 through August 2009. Water samples were also collected and physical properties were measured in each of the three major tributaries to Breckenridge Reservoir: North Branch Chopawamsic Creek, Middle Branch Chopawamsic Creek, and South Branch Chopawamsic Creek. One site on each tributary was sampled at least five times during the study.

Monthly profiles were conducted for water temperature, dissolved-oxygen concentrations, specific conductance, $\mathrm{pH}$, and turbidity measured at 2-foot intervals throughout the water column of the reservoir. These profiles were conducted at nine sites in the reservoir, and data values were measured at these sites from the water surface to the bottom of the reservoir. These profiles were conducted along three cross sections and were used to define the characteristics of the entire water column of the reservoir.

The analytical results of reservoir and tributary samples collected and physical properties measured during this study were compared to ambient water-quality standards of the Virginia Department of Environmental Quality and Virginia
\end{abstract}

State Water Control Board. Water temperature, dissolvedoxygen concentration, specific conductance, $\mathrm{pH}$, and turbidity measured in Breckenridge Reservoir generally indicated a lack of stratification in the water column of the reservoir throughout the study period. This is unlike most other reservoirs in the region and may be influenced by the reservoir's relatively short length and the aerators that operate in the reservoir near the spillway. In general, the water-quality of Breckenridge Reservoir is similar to other reservoirs in the region, and the measurements made during this study indicate that the reservoir is healthy and is not in violation of published State Water Control Board ambient water-quality standards.

Water samples at three reservoir sites were analyzed for 53 pesticides, but only atrazine was found to be above the laboratory minimum reporting level. Atrazine concentrations of 0.008 and 0.010 microgram per liter near the surface and bottom of the reservoir, respectively, were found at all three sampling locations.

Bottom-material samples were collected for analysis of trace elements at all three reservoir sampling sites. Concentrations of arsenic, cadmium, and mercury in bottom material were similar to those analyzed in other reservoirs in the region. However, most other constituents that were collected from Breckenridge Reservoir, especially iron and lead, showed much higher concentrations than the other reservoirs.

During the course of the study, increased turbidity and Escherichia coli bacteria counts were observed during or after periods of increased tributary discharge, and Secchi-disk depths decreased during those same periods. These streamflow and water-quality indicators suggest a close relationship between Breckenridge Reservoir and its tributaries. 


\section{Introduction}

Water and bottom material samples were collected and physical properties were measured by the U.S. Geological Survey (USGS) at three sites in Breckenridge Reservoir, and physical properties were measured at six additional reservoir sites from September 2008 through August 2009. Water samples were also collected and physical properties were measured in each of the three major tributaries to Breckenridge Reservoir: North Branch Chopawamsic Creek, Middle Branch Chopawamsic Creek, and South Branch Chopawamsic Creek. Analytical results of the reservoir and tributary samples that were collected, as well as the physical properties measured during this study, were compared to the ambient water-quality standards of the Virginia Department of Environmental Quality (DEQ) and Virginia State Water Control Board (SWCB).

Breckenridge Reservoir, built in the late 1930s, is the principal water-supply source for the U.S. Marine Corps (USMC) Base, and also is used for recreational purposes, such as fishing, swimming, and canoeing. During periods of drought, the water level within Breckenridge Reservoir often is sustained by the transfer of water from Lunga Reservoir, a much larger reservoir also located on the USMC Base at Quantico, Virginia (Va.).

The U.S. Fish and Wildlife Service and the USMC Natural Resources and Environmental Affairs Branch cooperatively manage Breckenridge and Lunga Reservoirs. Because Breckenridge Reservoir is used for public water supply and for recreational activities, the USMC asked the USGS to evaluate the water quality of Breckenridge Reservoir and compare the analytical results of samples collected in the reservoir to available DEQ and SWCB ambient water-quality standards. In response to this request, the USGS Virginia Water Science Center collected and analyzed samples from September 2008 through August 2009 for these comparisons.

The SWCB classifies Breckenridge Reservoir as a Class III waterway (Commonwealth of Virginia State Water Control Board, 2011). The SWCB defines a Class III waterway as a "stream which contains a fair population of wild trout with carrying capacity depressed by natural factors or more commonly man-related land use practices. Land use activities may result in heavy siltation of the stream, destruction of banks and fish cover, water quality degradation, increased water temperature, etc. Most streams would be considered to be in the active state of degradation or recovery from degradation. Alteration in land use practices would generally improve carrying capacity of the stream" (Commonwealth of Virginia State Water Control Board, 2011).

Although the SWCB has established standards for dissolved-oxygen concentrations, $\mathrm{pH}$, and water temperature for Class III waterways, no other standards currently exist for reservoirs in Virginia. The SWCB is developing additional criteria for lake and reservoir environments that will address the normal seasonal transitions that affect water-quality conditions in these lacustrine systems. The data summarized and listed in this report can be compared to new standards published in the future.
For water-quality constituents having no SWCB criteria available, analytical results of this study were compared with information available from previous studies conducted on five other manmade reservoirs in the State (table 1; fig. 1). The Pea Hill Arm of Lake Gaston, located in the Piedmont Physiographic Province, was studied by the USGS between 1988 and 1990 (Woodside, 1994). Chickahominy, Diascund Creek, and Little Creek Reservoirs, located mainly in the Coastal Plain Physiographic Province with some of the Chickahominy Reservoir watershed located in the Piedmont, were studied between 1983 and 1986 (Lynch, 1992). In addition, Lunga Reservoir, also located on the USMC Base within 5 miles (mi) of Breckenridge Reservoir, was studied by the USGS in 2004 and 2005 (Lotspeich, 2007). These reservoirs are all much larger than Breckenridge Reservoir and serve as water-supply sources for the residents of southeastern Virginia.

Table 1. Physical characteristics of Breckenridge, Lunga, Pea Hill Arm of Lake Gaston, Chickahominy, Diascund Creek, and Little Creek Reservoirs, Virginia.

[Locations of the reservoirs shown in figure 1; $\mathrm{mi}^{2}$, square miles; ft, feet; Mgal, million gallons]

\begin{tabular}{|c|c|c|c|c|}
\hline Reservoir & $\begin{array}{c}\text { Total } \\
\text { drainage } \\
\text { area } \\
\left(\mathrm{mi}^{2}\right)\end{array}$ & $\begin{array}{l}\text { Reservoir } \\
\text { surface } \\
\text { area } \\
\left(\mathrm{mi}^{2}\right)\end{array}$ & $\begin{array}{l}\text { Maximum } \\
\text { depth } \\
\text { (ft) }\end{array}$ & $\begin{array}{l}\text { Volume } \\
\text { (Mgal) }\end{array}$ \\
\hline Breckenridge Reservoir & 17.4 & 0.07 & 38 & 391 \\
\hline Lunga Reservoir ${ }^{1}$ & 10.8 & 0.66 & 40 & 1,700 \\
\hline $\begin{array}{l}\text { Pea Hill Arm of Lake } \\
\text { Gaston }^{2}\end{array}$ & 27.1 & 2.2 & 50 & 8,400 \\
\hline Chickahominy Reservoir ${ }^{3}$ & 305 & 1.70 & 18 & 1,900 \\
\hline Diascund Reservoir ${ }^{3}$ & 43.6 & 2.01 & 24 & 3,900 \\
\hline Little Creek Reservoir ${ }^{3}$ & 4.50 & 1.48 & 58 & 7,480 \\
\hline \multicolumn{5}{|l|}{${ }^{1}$ From Lotspeich, 2007.} \\
\hline${ }^{2}$ From Woodside, 1994. & & & & \\
\hline 35rom Lynch, 1992. & & & & \\
\hline
\end{tabular}

\section{Purpose and Scope}

This report documents the analytical results of waterquality samples and data collected from September 2008 through August 2009 at nine sites in Breckenridge Reservoir, and three tributary streams that feed the reservoir. The sampling sites were selected to evaluate the overall quality of water within the reservoir and its source water. The waterquality results are compared to available SWCB standards for constituents that are considered to affect human and aquatic species. No samples were collected during January 2009, because the surface of the reservoir was frozen for most of the month. The ice was too thick to use a boat and too thin to work on safely. The analytical results of sampling for physical, chemical, and biological constituents are summarized in the following sections. 

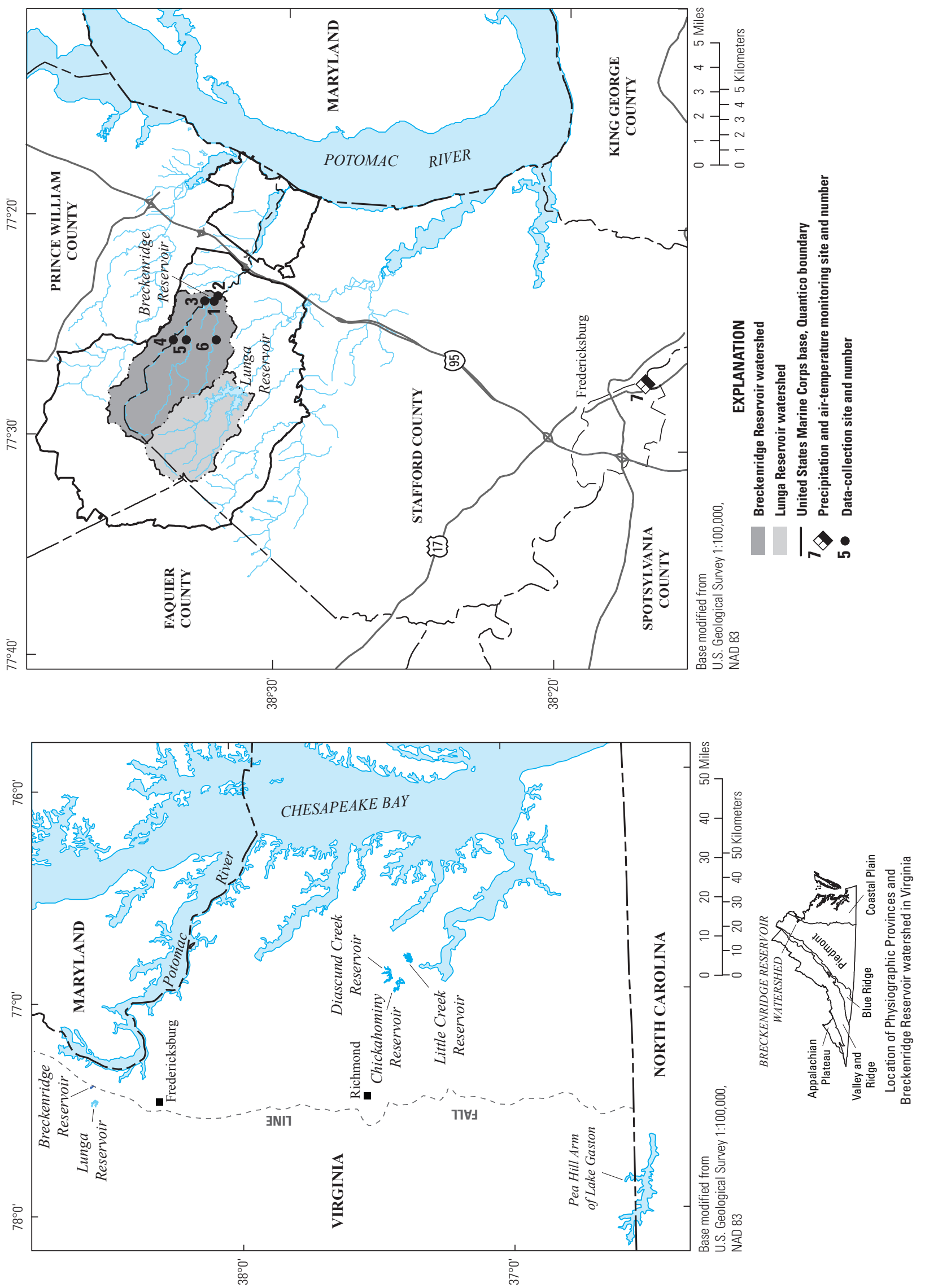

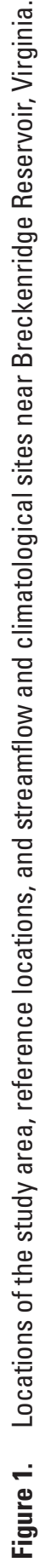




\section{Description of Study Area}

Breckenridge Reservoir is located on the USMC Base at Quantico in the Potomac River basin and the Piedmont Physiographic Province of northern Virginia (fig. 1). The reservoir is impounded by a concrete dam with a spillway elevation of approximately 130 feet (ft), as referenced to North American Vertical Datum of 1988 (NAVD 88). Two streams feed the reservoir: Chopawamsic Creek and South Branch Chopawamsic Creek. North Branch and Middle Branch converge and form Chopawamsic Creek about $1 \mathrm{mi}$ above the reservoir, and South Branch flows farther downstream, and enters near the middle of the reservoir (fig. 2).

Breckenridge Reservoir is impounded by a concrete dam, has a storage capacity of 391 million gallons (Mgal), covers about 45 acres (William Cross, U.S. Marine Corps, Quantico, Va., written commun., 2011), and has a maximum depth of about $38 \mathrm{ft}$ near the spillway. Water from the reservoir spills over the dam and flows downstream for $6 \mathrm{mi}$ where it flows into the Potomac River in Stafford County (fig. 1).
The Breckenridge Reservoir watershed has a drainage area of 17.4 square miles $\left(\mathrm{mi}^{2}\right.$; tables 1,2$)$. The area surrounding Breckenridge Reservoir is about 93 percent forested and less than $(<) 1$ percent urbanized (table 2). The USMC grants reservoir access to only a small number of visitors each year; it also operates multiple rifle shooting ranges in the upper part of the watershed.

\section{Historical Streamflow and Climatological Data in the Study Area}

Historical streamflow data are available from USGS streamgaging stations located on the reservoir tributary streams: North Branch Chopawamsic Creek near Independent Hill, Va. (01659000), Middle Branch Chopawamsic Creek near Garrisonville, Va. (01659500), and South Branch Chopawamsic Creek near Garrisonville, Va. (01660000). These historical data were compared to streamflow data collected during the study period (fig. 3). Streamflow records

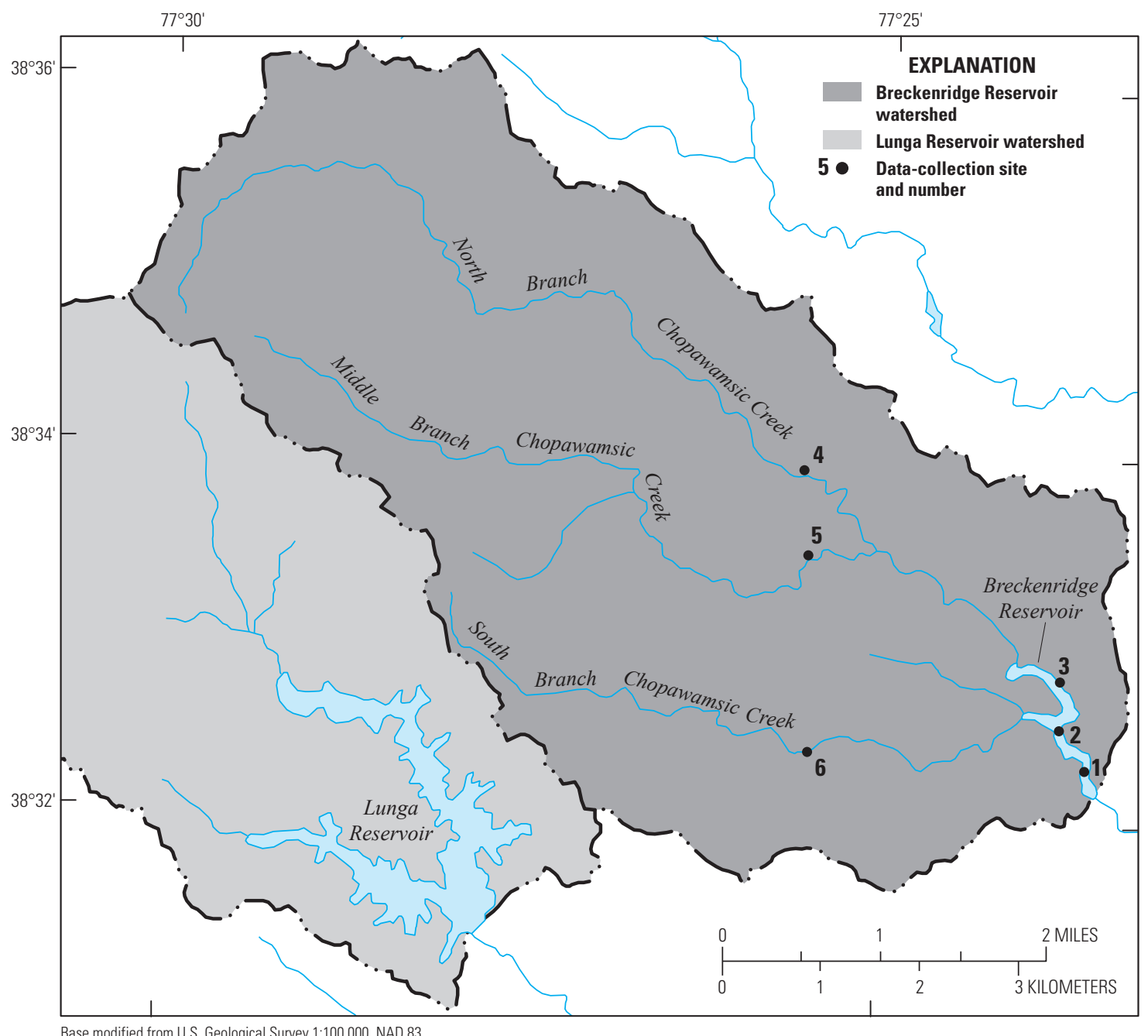

Figure 2. Breckenridge Reservoir, watershed, tributary streams, and sampling sites in Virginia. 
Table 2. Watershed land use around Breckenridge Reservoir, Virginia.

[mi ${ }^{2}$, square miles]

\begin{tabular}{lcc}
\hline \multicolumn{1}{c}{$\begin{array}{c}\text { Land-use } \\
\text { classification }\end{array}$} & $\begin{array}{c}\text { Total area } \\
\left(\mathbf{m i}^{\mathbf{2}}\right)\end{array}$ & $\begin{array}{c}\text { Percentage of } \\
\text { watershed }\end{array}$ \\
\hline Forest & 16.2 & 93.0 \\
Agricultural & 0.48 & 2.75 \\
Wetlands & 0.13 & 0.76 \\
Open water & 0.03 & 0.19 \\
Urban/developed & 0.16 & 0.92 \\
Barren land & 0.22 & 1.28 \\
Grassland & 0.19 & 1.10 \\
\hline Total & 17.4 & 100 \\
\hline
\end{tabular}

${ }^{1}$ From Goetz and others, 2004. from the gaging stations on the tributary streams indicate that flow in the tributary streams was near the mean monthly streamflow for the period of record. Likewise, the total amount of precipitation measured during the study was also near the long-term average. Published National Weather Service precipitation data collected at the Fredericksburg Sewage Treatment Plant indicate that a total of 39.5 inches (in.) of precipitation fell during the period of study, slightly below the long-term annual average of 43 in. (fig. 1, site 7).

\section{Sample Collection and Analysis}

Sites were selected and samples were collected through a cooperative effort between the USMC and USGS. Water samples were collected once a month (except in January) at a depth of 1.0-ft at sites in the reservoir; sample collection was consistent with sampling protocols of the DEQ. Samples also were collected from near the bottom of the water column only at reservoir sampling sites in December 2008 and August 2009.

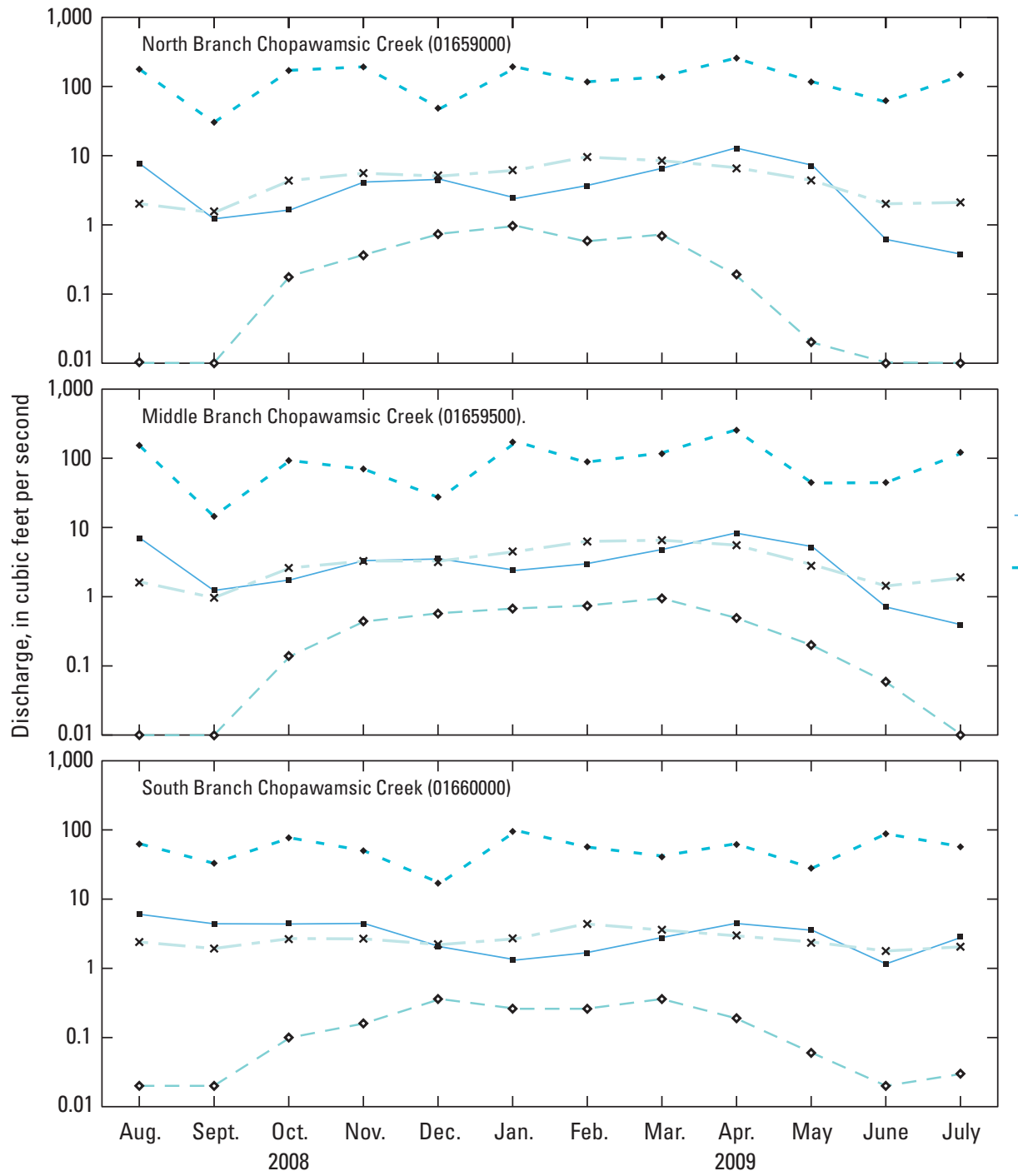

EXPLANATION

2009 mean discharge

Period of record

Maximum discharge

Minimum discharge

Mean discharge
Figure 3. Mean monthly discharge in water year 2009, and maximum, minimum, and mean monthly discharges for the period of record at North Branch Chopawamsic Creek (01659000), Middle Branch Chopawamsic Creek (01659500), and South Branch Chopawamsic Creek (01660000) near Breckenridge Reservoir, Virginia. 
Three primary sample-collection sites were selected in Breckenridge Reservoir (fig. 1; table 3). One sampling site was located at the downstream end of the reservoir just above the spillway (fig. 4, site 1). Another sampling site was located near the center of the reservoir just below the mouth of South Branch Chopawamsic Creek (fig. 4, site 2). The third site was located in the upper part of the reservoir above the confluence with South Branch Chopawamsic Creek (fig. 4, site 3). These three primary sample-collection sites were located near the middle of the channel where the reservoir depth was greatest.

Six additional sites in the reservoir were used as cross-section profiling points where physical properties were periodically measured (fig. 4). These sites were paired with the primary sampling sites to form cross-sections that partially traversed the width of the reservoir to document any variability in water chemistry across the reservoir. At these cross sections, measurements of water temperature, specific conductance, $\mathrm{pH}$, dissolved oxygen, and turbidity were made from the water surface to the bottom of the reservoir. These measurements were taken monthly at 2-ft intervals throughout the water column.

To document the characteristics of water flowing into the reservoir, water-quality samples were collected at USGS streamgaging sites on three tributary streams (fig. 1, sites 4-6). These tributary stream sites were generally sampled on a quarterly basis in an attempt to capture seasonal variations in water-quality conditions.

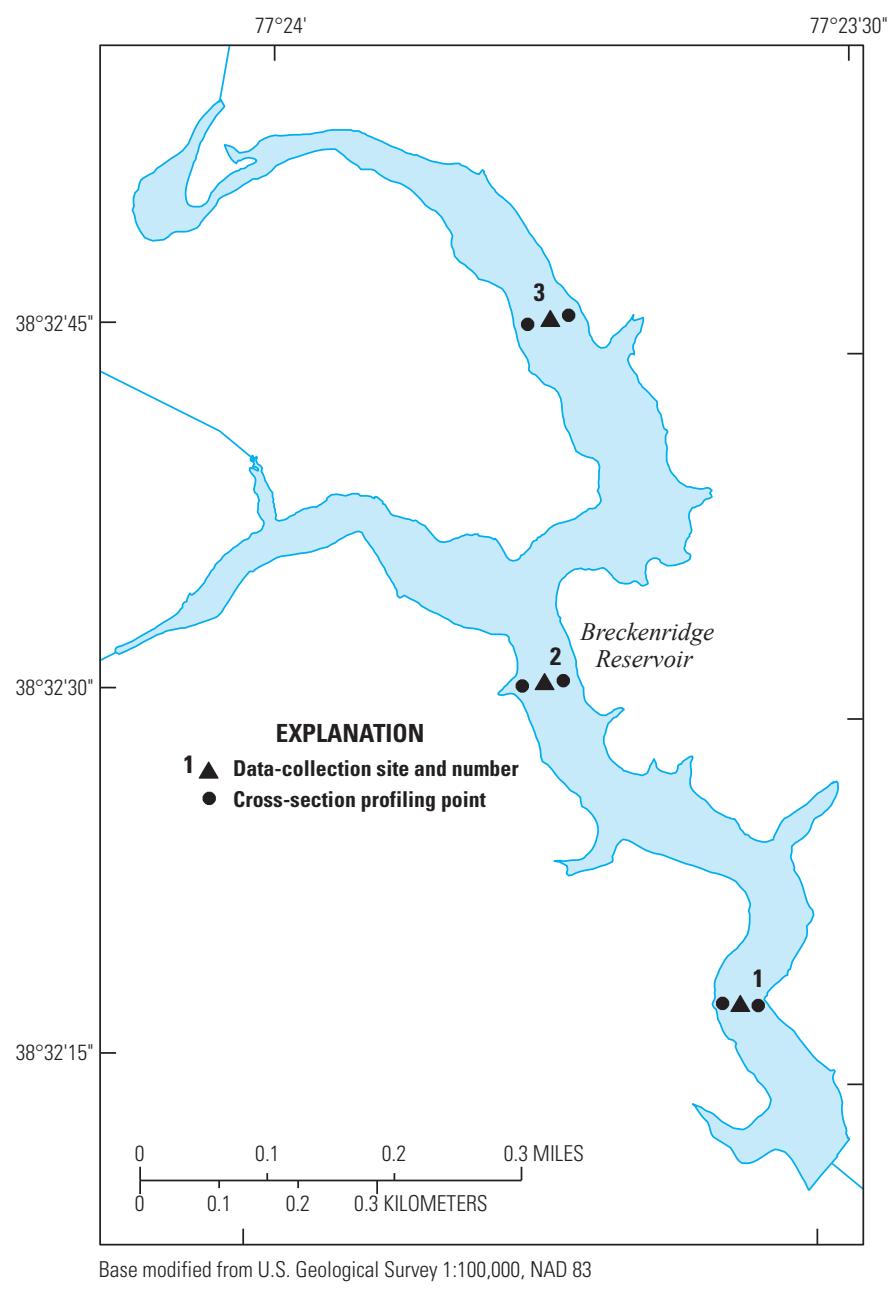

Figure 4. Location of sampling sites and cross-section profiling points in Breckenridge Reservoir, Virginia.

Table 3. Data-collection and reference sites for Breckenridge Reservoir, Virginia, September 2008 through August 2009.

[USGS, U.S. Geological Survey; ft, feet; na, not applicable; NOAA, National Oceanic and Atmospheric Administration. Data type: P, periodic water-quality; $\mathrm{R}$, rainfall; $\mathrm{D}$, discharge. Site numbers shown in figure 1]

\begin{tabular}{|c|c|c|c|c|c|c|}
\hline $\begin{array}{c}\text { Site } \\
\text { number }\end{array}$ & $\begin{array}{l}\text { Site name and } \\
\text { USGS identification number }\end{array}$ & Latitude & Longitude & $\begin{array}{c}\text { Mean } \\
\text { depth } \\
(\mathrm{ft})\end{array}$ & $\begin{array}{l}\text { Data } \\
\text { type }\end{array}$ & $\begin{array}{c}\text { Data } \\
\text { source }\end{array}$ \\
\hline 1 & Breckenridge Reservoir above Dam near Joplin (01660030) & $38^{\circ} 32^{\prime} 18^{\prime \prime}$ & $77^{\circ} 23^{\prime} 34^{\prime \prime}$ & 29.6 & $\mathrm{P}$ & USGS \\
\hline 2 & $\begin{array}{l}\text { Breckenridge Reservoir below South Branch Chopawamsic Creek } \\
\text { near Joplin }(01660020)\end{array}$ & $38^{\circ} 32^{\prime} 31^{\prime \prime}$ & $77^{\circ} 23^{\prime} 45^{\prime \prime}$ & 23.1 & $\mathrm{P}$ & USGS \\
\hline 3 & $\begin{array}{l}\text { Breckenridge Reservoir above South Branch Chopawamsic Creek } \\
\text { near Joplin (01659700) }\end{array}$ & $38^{\circ} 32^{\prime} 46^{\prime \prime}$ & $77^{\circ} 23^{\prime} 45^{\prime \prime}$ & 8.3 & $\mathrm{P}$ & USGS \\
\hline 4 & $\begin{array}{l}\text { North Branch Chopawamsic Creek near Independent Hill } \\
\quad(01659000)\end{array}$ & $38^{\circ} 33^{\prime} 54^{\prime \prime}$ & $77^{\circ} 25^{\prime} 34^{\prime \prime}$ & na & $\mathrm{D}, \mathrm{P}$ & USGS \\
\hline 5 & Middle Branch Chopawamsic Creek near Garrisonville (01659500) & $38^{\circ} 33^{\prime} 26^{\prime \prime}$ & $77^{\circ} 25^{\prime} 32^{\prime \prime}$ & na & $\mathrm{D}, \mathrm{P}$ & USGS \\
\hline 6 & South Branch Chopawamsic Creek near Garrisonville (01660000) & $38^{\circ} 32^{\prime} 22^{\prime \prime}$ & $77^{\circ} 25^{\prime} 30^{\prime \prime}$ & na & $\mathrm{D}, \mathrm{P}$ & USGS \\
\hline 7 & Fredericksburg Sewage (443204) & $38^{\circ} 17^{\prime}$ & $77^{\circ} 27^{\prime}$ & na & $\mathrm{R}$ & NOAA \\
\hline
\end{tabular}


Water temperature, dissolved-oxygen concentration, specific conductance, $\mathrm{pH}$, turbidity, and Secchi-disk depths were measured monthly at the three primary reservoir samplecollection sites and the six reservoir cross-section profiling points (fig. 4). Concentrations of major ions, nutrients, silica, organic carbon, alkalinity, and Escherichia coliform (E. coli) bacteria were determined from monthly samples collected at the three reservoir sampling sites. Concentrations for these same constituents were determined for samples that were collected from the three tributary streams. Samples from the streams were generally collected on a quarterly basis. Water samples at the three reservoir sites were collected in December 2008 and again in August 2009 for analysis of pesticides. In addition, bottom-material samples were collected from the three reservoir sites in July 2009 and were analyzed for trace-element concentrations.

Water temperature, dissolved-oxygen concentration, specific conductance, $\mathrm{pH}$, and turbidity were measured at all reservoir and stream sites using a multiparameter water-quality meter. The meter was calibrated according to published USGS guidelines before making field measurements (Wilde and others, 1999). Alkalinity of a filtered water sample was determined by the incremental titration method using a digital titrator with 0.16-normality $(\mathrm{N})$ sulfuric acid and a calibrated $\mathrm{pH}$ meter. Secchi-disk depths were measured by lowering a white disk into the water until it was no longer visible. Water samples were collected as grab samples by lowering the sample bottle about $1 \mathrm{ft}$ below the water surface and holding it in place until the bottle filled. Twice during the study, December 2008 and August 2009, water samples also were collected from near the bottom of the water column at the three reservoir sampling sites. These samples were collected using weighted Teflon ${ }^{\circledR}$ tubing and a peristaltic pump.

Bacteria and alkalinity sample processing and analyses were conducted by the USGS Virginia Water Science Center. Samples collected for bacteriological analysis were processed onsite within the 6-hour holding time and placed in pre-heated incubators for 20 to 24 hours (Myers and Wilde, 2003).

Prepared E. coli m-TEC medium was poured into sterile petri dishes where the 47 -millimeter $(\mathrm{mm}), 0.45$ micrometer $(\mu \mathrm{m})$ filters were placed. E. coli colonies were counted following the incubation period.

Whole, unfiltered water samples were analyzed for concentrations of total nitrogen, total phosphorus, bacteria, and total organic carbon (TOC; app. 1). Total nitrogen and total phosphorus samples were collected in clean, 125-milliliter $(\mathrm{mL})$, clear polyethylene bottles that were rinsed with native water three times just prior to sample collection. Samples were preserved with $2 \mathrm{~mL}$ of $4.5-\mathrm{N}$ sulfuric acid. Samples for bacteriological analysis were collected in unrinsed $500-\mathrm{mL}$ borosilicate bottles that had been sterilized in an autoclave. Samples collected for TOC analysis were collected in unrinsed $125-\mathrm{mL}$ amber glass bottles that had been baked at 450 degrees Celsius $\left({ }^{\circ} \mathrm{C}\right)$.
Water for filtered samples was collected in 3-liter (L) Teflon ${ }^{\circledR}$ bottles. Before each sampling event, these bottles were cleaned according to USGS guidelines (Wilde and others, 1999). After initial collection, water to be analyzed for dissolved constituents was pumped from the sample bottle through clean Teflon ${ }^{\circledR}$ tubing using a peristaltic pump and then filtered into bottles through a clean $0.45-\mu \mathrm{m}$ pore-size capsule filter. Filtrate to be analyzed for concentrations of calcium, magnesium, potassium, silica, and sodium was bottled in clean, acid-rinsed, 250-mL, clear polyethylene bottles and preserved with $2 \mathrm{~mL}$ of nitric acid. Filtrate to be analyzed for concentrations of chloride, fluoride, and sulfate was bottled in clean, filtrate-rinsed, $500-\mathrm{mL}$, clear polyethylene bottles. Filtrate to be analyzed for concentrations of ammonia, nitrite, nitrite plus nitrate, total dissolved nitrogen, dissolved phosphorus, and dissolved orthophosphate was bottled in clean, filtrate-rinsed, $125-\mathrm{mL}$, brown polyethylene bottles. Filtrate to be analyzed for dissolved organic carbon (DOC) was collected in baked, unrinsed, $125-\mathrm{mL}$ amber glass bottles and preserved with $2 \mathrm{~mL}$ of $4.5-\mathrm{N}$ sulfuric acid.

Laboratory analyses were conducted at the USGS National Water Quality Laboratory (NWQL) in Denver, Colorado. Water samples were chilled and shipped overnight to the NWQL for analysis. Periodic qualityassurance samples were collected and analyzed to evaluate field and laboratory procedures. Field blanks were sent to the NWQL for analysis in December 2008 and August 2009 to identify potential contamination field collection, sample processing, shipping, and laboratory processing.

Replicate samples were sent to the NWQL for analysis in December 2008 and in May, July, and August 2009 to evaluate laboratory reproducibility of results. Field measurements and analytical results were recorded and stored in the USGS National Water Information System (NWIS) database.

In December 2008 and August 2009, water samples to be analyzed for concentrations of 53 pesticides were collected at the three sampling sites in the reservoir at 1 - $\mathrm{ft}$ below the water surface and near the bottom of the water column. These reservoir samples were collected and stored in unrinsed, 1-L amber glass bottles that had been baked at $450{ }^{\circ} \mathrm{C}$ (app. 2).

Bottom-material samples were collected from the three reservoir sampling sites in July 2009 using a dredge-style sampler. These samples were sent to the NWQL where they were analyzed for concentrations of 12 trace elementsarsenic, cadmium, chromium, cobalt, copper, iron, lead, manganese, mercury, nickel, selenium, and zinc. A second bottom-material sample was collected from each reservoir sampling location and sent to the Test America Laboratory in Colorado for analysis of phosphorus. This additional bottommaterial sampling and analysis was done through a contract that was written by the NWQL, and the results of these analyses are stored in the USGS NWIS database. 


\section{Water Quality of Reservoir Sites}

Water-quality samples were collected monthly at three sampling sites in Breckenridge Reservoir. Physical properties, which included water temperature, dissolved-oxygen, specific conductance, $\mathrm{pH}$, turbidity, and Secchi-disk depths, were also measured at the three sample-collection sites and at six additional sites (fig. 4). Chemical constituents, which included nutrients, organic carbon, major-ions, alkalinity, silica, and pesticides, were analyzed from water samples taken at the three reservoir sampling sites. Samples from the reservoir sites were also analyzed for E. coli bacteria. The trophic status of the reservoir was also evaluated using data collected during the study.

\section{Physical Properties}

Measurements of water temperature, dissolved-oxygen concentrations, specific conductance, $\mathrm{pH}$, and turbidity were made at nine sites that formed three cross-sections in Breckenridge Reservoir, and these measurements provide a general understanding of the water quality in the reservoir. Measurements made throughout the water column at these sites did not indicate a vertical variability or stratification that typically is observed in lakes and reservoirs in eastern Virginia during warm-weather months.
A thermocline is a transition layer between deep and shallow water where changes in water chemistry (commonly negative) occur with increasing depth. Although no thermocline was observed in Breckenridge Reservoir, a thermocline was observed in Lunga Reservoir during the summer and early fall between depths of 10 to $20 \mathrm{ft}$ where the water temperature dropped nearly $20^{\circ} \mathrm{C}$, dissolved oxygen reached near-zero concentration, and specific conductance more than doubled near the bottom (Lotspeich, 2007).

Due to the lack of a thermocline and spatial variability of the physical properties that were measured throughout Breckenridge Reservoir, the following sections include graphs (figs. 5-9) showing depth-averaged data. These data points are the average measurements of all three reservoir sampling sites taken within 5-ft-depth intervals and compiled over each season (apps. 3-5). These plots in the graphs are intended to illustrate the general change in water chemistry over the year, which was consistent throughout the reservoir.

\section{Water Temperature}

Water temperature is a measure of the warmth or coldness of the water that directly affects many physical, chemical, and biological processes. Water temperature measured at 1.0-ft depth throughout Breckenridge Reservoir ranged from 3.6 to $27.2^{\circ} \mathrm{C}$ (table 4 ). Water temperature measured at 2 -ft-depth intervals throughout the water column at the nine reservoir sites ranged from 3.2 to $27.7^{\circ} \mathrm{C}$ (apps. 3-5).

Table 4. Summary of physical properties at 1-foot depth for sampling sites in Breckenridge Reservoir and tributaries, Virginia, September 2008 through August 2009.

[USGS, U.S. Geological Survey; ${ }^{\circ} \mathrm{C}$, degrees Celsius; mg/L, milligrams per liter; $\mu \mathrm{S} / \mathrm{cm}$, microsiemens per centimeter at $25^{\circ} \mathrm{C}$; units, standard $\mathrm{pH}$ units; FNU, formazin nephelometric units; - , no data]

\begin{tabular}{|c|c|c|c|c|c|c|c|c|c|c|c|c|}
\hline \multirow{2}{*}{$\begin{array}{c}\text { Site } \\
\text { number }\end{array}$} & \multirow{2}{*}{$\begin{array}{c}\text { Site name } \\
\text { and } \\
\text { USGS identification number }\end{array}$} & \multirow{2}{*}{$\begin{array}{l}\text { Number } \\
\text { of } \\
\text { samples }\end{array}$} & \multicolumn{2}{|c|}{$\begin{array}{c}\text { Water } \\
\text { temperature } \\
\left({ }^{\circ} \mathrm{C}\right)\end{array}$} & \multicolumn{2}{|c|}{$\begin{array}{l}\text { Dissolved } \\
\text { oxygen } \\
\text { (mg/L) }\end{array}$} & \multicolumn{2}{|c|}{$\begin{array}{c}\text { Specific } \\
\text { conductance } \\
(\mu \mathrm{S} / \mathrm{cm})\end{array}$} & \multicolumn{2}{|c|}{ pH (units) } & \multicolumn{2}{|c|}{ Turbidity (FNU) } \\
\hline & & & $\begin{array}{c}\text { Mini- } \\
\text { mum }\end{array}$ & $\begin{array}{l}\text { Max- } \\
\text { imum }\end{array}$ & $\begin{array}{l}\text { Mini- } \\
\text { mum }\end{array}$ & $\begin{array}{l}\text { Max- } \\
\text { imum }\end{array}$ & $\begin{array}{l}\text { Mini- } \\
\text { mum }\end{array}$ & $\begin{array}{l}\text { Max- } \\
\text { imum }\end{array}$ & $\begin{array}{l}\text { Mini- } \\
\text { mum }\end{array}$ & $\begin{array}{l}\text { Max- } \\
\text { imum }\end{array}$ & $\begin{array}{l}\text { Mini- } \\
\text { mum }\end{array}$ & $\begin{array}{l}\text { Max- } \\
\text { imum }\end{array}$ \\
\hline 1 & $\begin{array}{l}\text { Breckenridge Reservoir above Dam near } \\
\text { Joplin }(01660030)\end{array}$ & 11 & 4.7 & 26.7 & 4.4 & 9.3 & 38 & 94 & 6.0 & 8.6 & 3.0 & 10.3 \\
\hline 2 & $\begin{array}{l}\text { Breckenridge Reservoir below South Branch } \\
\text { Chopawamsic Creek near Joplin (01660020) }\end{array}$ & 11 & 4.7 & 27.2 & 3.9 & 9.4 & 37 & 94 & 5.9 & 8.5 & 1.9 & 11.4 \\
\hline 3 & $\begin{array}{l}\text { Breckenridge Reservoir above South Branch } \\
\text { Chopawamsic Creek near Joplin (01659700) }\end{array}$ & 11 & 3.6 & 27.2 & 3.9 & 9.9 & 37 & 93 & 5.8 & 8.6 & 2.0 & 9.4 \\
\hline 4 & $\begin{array}{l}\text { North Branch Chopawamsic Creek near } \\
\text { Independent Hill (01659000) }\end{array}$ & 12 & 2.2 & 20.0 & 6.6 & 13.6 & 38 & 98 & 6.0 & 7.9 & - & - \\
\hline 5 & $\begin{array}{l}\text { Middle Branch Chopawamsic Creek near } \\
\text { Garrisonville (01659500) }\end{array}$ & 5 & 2.3 & 21.0 & 8.5 & 10.9 & 31 & 42 & 6.1 & 7.9 & - & - \\
\hline 6 & $\begin{array}{l}\text { South Branch Chopawamsic Creek near } \\
\text { Garrisonville (01660000) }\end{array}$ & 5 & 2.6 & 21.2 & 7.8 & 11.3 & 37 & 62 & 5.9 & 7.8 & - & - \\
\hline
\end{tabular}




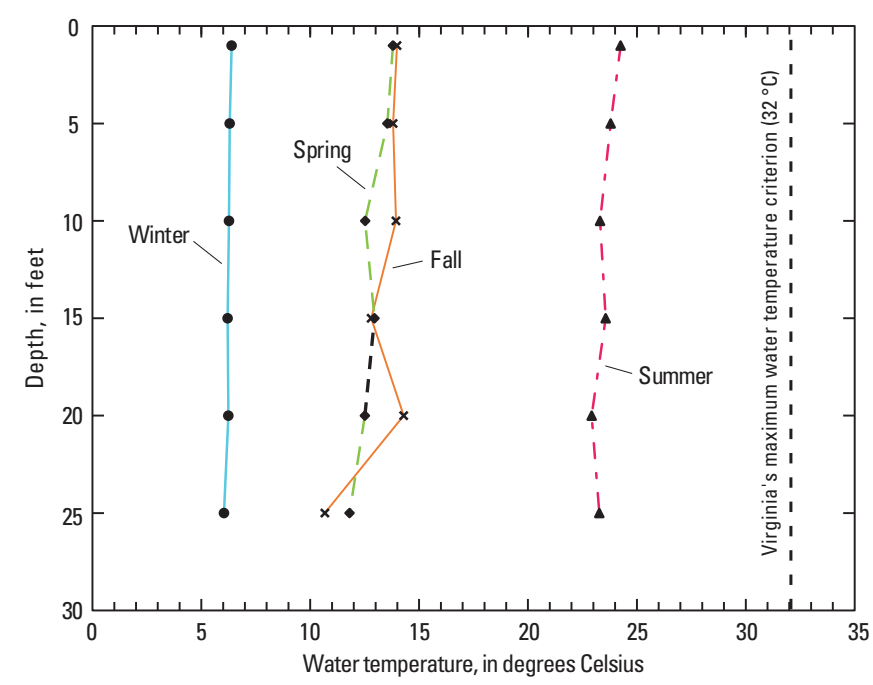

Figure 5. Depth-averaged seasonal water temperature for Breckenridge Reservoir, Virginia, September 2008 through August 2009.

All water temperatures measured during the study were below the maximum ambient water-quality temperature criteria $\left(32^{\circ} \mathrm{C}\right.$ ) for Class III waterways (Commonwealth of Virginia State Water Control Board, 2011).

Lack of a thermal gradient was observed at all nine sites in Breckenridge Reservoir during the spring and summer months (fig. 5). Throughout the 12-month study period, water temperatures at all of the reservoir sites generally were constant throughout the water column, with relatively small changes of up to $2.9^{\circ} \mathrm{C}$.

\section{Dissolved Oxygen}

Dissolved oxygen is a measurement of the available oxygen molecules dissolved in water that directly affect the ability of aquatic organisms to survive. Dissolved-oxygen concentrations also affect numerous chemical reactions. During the colder months, the rate of consumption of oxygen in a reservoir may decrease due to colder water temperatures and because the solubility of oxygen increases as water temperature decreases. Dissolved-oxygen concentrations measured in Breckenridge Reservoir generally were higher during the colder months and lower during warmer months and showed little variation with depth (fig. 6).

Dissolved-oxygen concentrations measured at 1.0-ft depth throughout Breckenridge Reservoir ranged from 3.9 to 9.9 milligrams per liter (mg/L; table 4). Dissolvedoxygen concentrations measured at 2 -ft-depth intervals throughout the water column at all nine reservoir sites ranged from 2.8 to $11.7 \mathrm{mg} / \mathrm{L}$ (apps. 3-5). The Virginia SWCB lists the minimum dissolved-oxygen concentration ambient water-quality

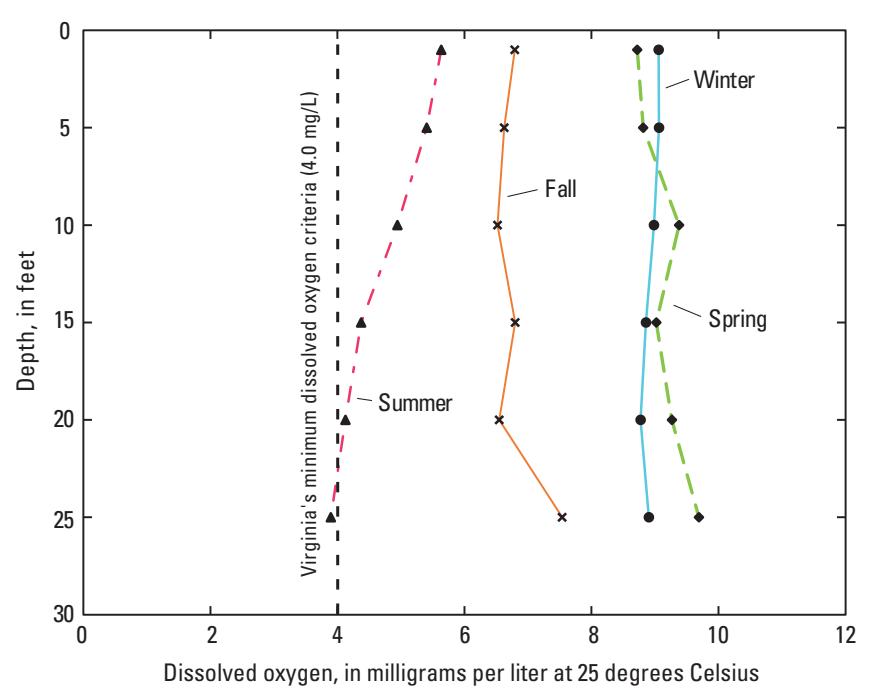

Figure 6. Depth-averaged seasonal dissolved oxygen for Breckenridge Reservoir, Virginia, September 2008 through August 2009.

standard for Class III waterways as $4.0 \mathrm{mg} / \mathrm{L}$ (Commonwealth of Virginia State Water Control Board, 2011). Dissolvedoxygen concentrations measured in Breckenridge Reservoir during the study were below the SWCB criterion at two sampling sites in September 2008. All other measurements of dissolved-oxygen at 1.0-ft depth in Breckenridge Reservoir were above the $4.0 \mathrm{mg} / \mathrm{L}$ criterion.

\section{Specific Conductance}

Specific conductance is a measure of how well a solution at $25{ }^{\circ} \mathrm{C}$ conducts an electrical current. As the amount of negatively and positively charged ions increase in an aqueous solution, the conductance of an electrical current by the solution also increases. Therefore, water with low ability to conduct an electrical current has low specific conductance, which in turn indicates low ionic concentration and indicates generally better water quality.

Specific conductance measured at 1.0-ft depth throughout Breckenridge Reservoir ranged from 37 to 94 microsiemens per centimeter $(\mu \mathrm{S} / \mathrm{cm})$ at $25^{\circ} \mathrm{C}($ table 4$)$, which indicates a low ionic activity in the waters of the reservoir (Wetzel, 2001). Specific conductance measured at 2-ft-depth intervals throughout the water column at all nine reservoir sites indicated that no substantial stratification was present in the reservoir throughout the study period (fig. 7; apps. 3-5). The highest specific conductance concentrations in the reservoir, 93 to $99 \mu \mathrm{S} / \mathrm{cm}$, were measured in June 2009.

Although the SWCB has no criteria for specific conductance, the mean specific conductance in Breckenridge Reservoir during the study $(52 \mu \mathrm{S} / \mathrm{cm})$ was lower than the mean specific conductance in other reservoirs in the State. 


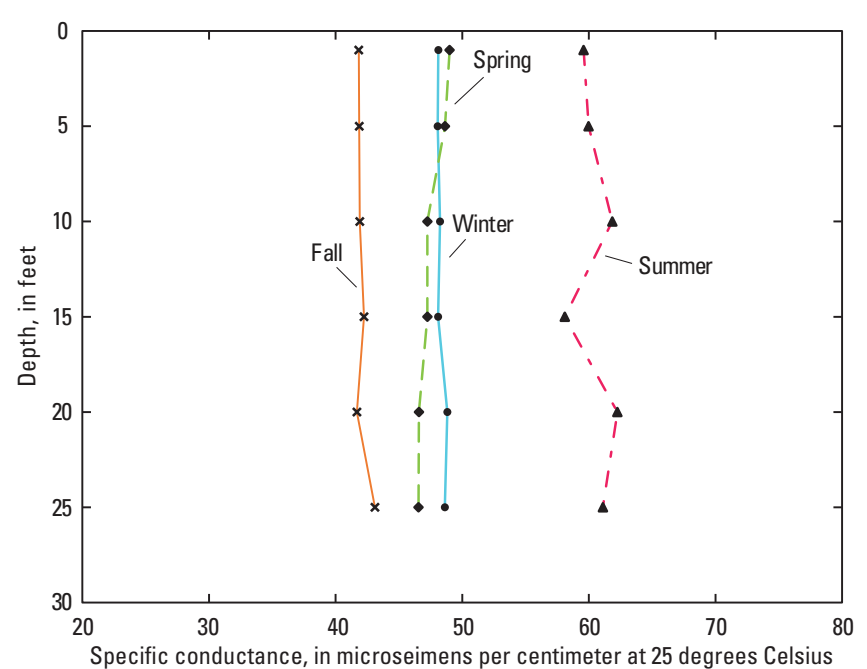

Figure 7. Depth-averaged seasonal specific conductance for Breckenridge Reservoir, Virginia, September 2008 through August 2009.

By comparison, from 2004 to 2005, a mean specific conductance of $68 \mu \mathrm{S} / \mathrm{cm}$ was measured in Lunga Reservoir (Lotspeich, 2007), and a mean specific conductance of $90 \mu \mathrm{S} / \mathrm{cm}$ was measured in the Pea Hill Arm of Lake Gaston Reservoir from 1988 to 1990 (Woodside, 1994). In addition, mean specific conductance values of 118,81 , and $117 \mu \mathrm{S} / \mathrm{cm}$ were measured in the Chickahominy, Diascund Creek, and Little Creek Reservoirs, respectively, from 1983 to 1986 (Lynch, 1992).

\section{$\mathrm{pH}$}

$\mathrm{pH}$ is a measure of the activity of the hydrogen ion $(\mathrm{H}+)$. Natural lake waters that have low $\mathrm{pH}$ usually are rich in dissolved organic material, and high $\mathrm{pH}$ waters usually contain high concentrations of salts (Wetzel, 2001). According to Wetzel (2001), the $\mathrm{pH}$ of most open lakes ranges from 6.0 to 9.0 , which is consistent with the $\mathrm{pH}$ of other reservoirs in Virginia.

The $\mathrm{pH}$ measured at 1.0- $\mathrm{ft}$ depth throughout Breckenridge Reservoir ranged from 5.8 to 8.6 standard units during the year (table 4). The $\mathrm{pH}$ measured at 2-ft intervals throughout the water column at the nine reservoir sites ranged from 5.6 to 8.6 standard units and generally was lowest during the late summer, increased through winter, and peaked in March, showing little spatial variability (fig. 8; apps. 3-5). The SWCB pH criterion for Class III waterways is a range of 6.0 to 9.0 standard units (Commonwealth of Virginia State Water Control Board, 2011). The $\mathrm{pH}$ values measured at 1.0-ft depth at all sites in Breckenridge Reservoir fell just below the minimum SWCB standard in September 2008. The $\mathrm{pH}$ values measured at all sites in the reservoir were below the

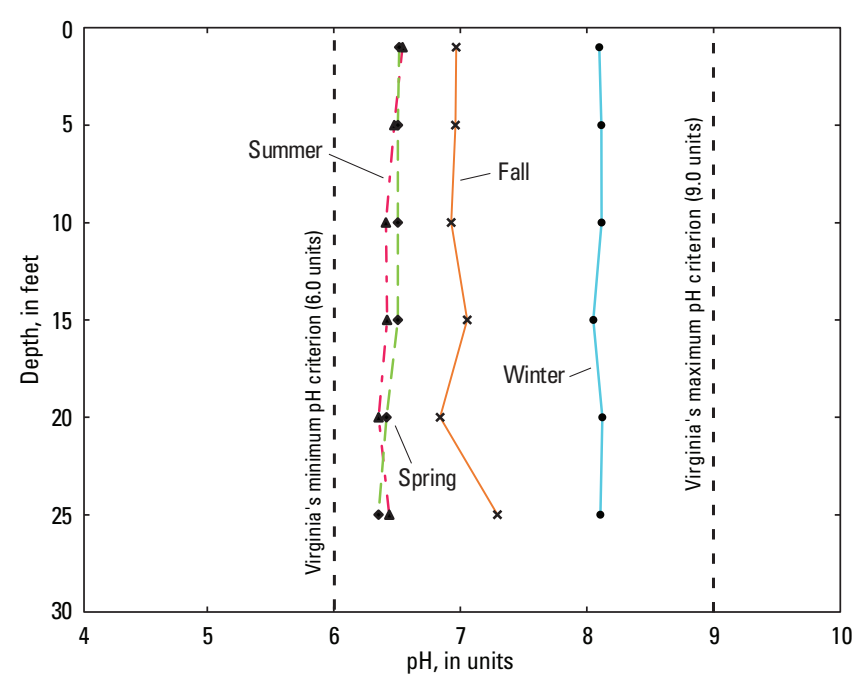

Figure 8. Depth-averaged seasonal $\mathrm{pH}$ for Breckenridge Reservoir, Virginia, September 2008 through August 2009.

maximum SWCB pH standard during the entire study period. By comparison, Lunga Reservoir had $\mathrm{pH}$ measurements that ranged from 4.8 to 7.6 standard units during 2004 to 2005 (Lotspeich, 2007). In the Pea Hill Arm of Lake Gaston Reservoir, $\mathrm{pH}$ values ranged from 6.8 to 8.2 standard units from 1988 to 1990 (Woodside, 1994). The Chickahominy, Diascund Creek, and Little Creek reservoirs had $\mathrm{pH}$ values that ranged from 6.0 to $7.0,6.5$ to 7.0 , and 6.5 to 7.5 standard units, respectively, from 1983 to 1986 (Lynch, 1992).

\section{Water Clarity}

Water clarity in Breckenridge Reservoir was assessed during the study period by measuring two different indicators - turbidity and Secchi-disk depth. Turbidity isa visual property of water that is measured optically with an instrument. Increased turbidity suggests a reduction in clarity resulting from the presence of increased suspended particles (Wetzel, 2001). The Secchi-disk depth is a visual measurement of the vertical extinction of light in natural waters (Wetzel, 2001). Factors that limit the ability to accurately measure Secchi-disk depth include the time of day (amount and angle of sunlight), water color, physical condition of the Secchi-disk, and the visual acuity of the person taking the reading.

Turbidity measured at $1.0-\mathrm{ft}$ depth throughout Breckenridge Reservoir ranged from 1.9 to 11.4 formazin nephelometric units (FNU; table 4). Turbidity measured at 2 -ft-depth intervals throughout the water column at the nine reservoir sites ranged from 1.6 to $<61.7 \mathrm{FNU}$ (fig. 9; apps. 3-5). The higher turbidity values were observed near the bottom of the water column and were likely the result of particles settling near the bottom. No turbidity data were collected in May 2009 due to a malfunctioning turbidity probe. 


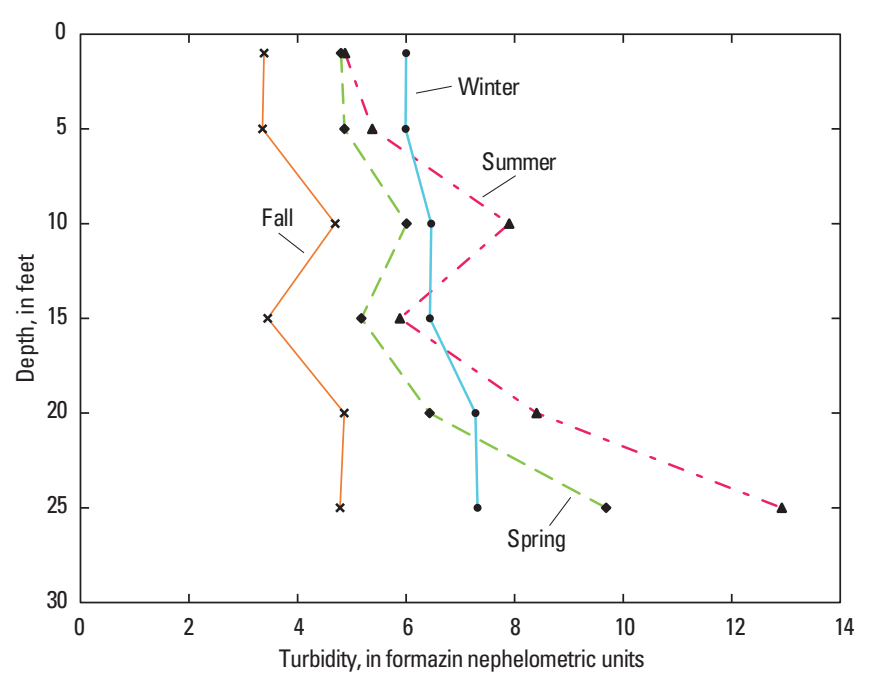

Figure 9. Depth-averaged seasonal turbidity for Breckenridge Reservoir, Virginia, September 2008 through August 2009.

Secchi-disk depths measured at the three sampling sites in Breckenridge Reservoir ranged from 2.8 to $5.8 \mathrm{ft}$ (app. 6). The deepest Secchi-disk depths were recorded in February 2009. The shallowest Secchi-disk depths were recorded in December 2008 and June 2009 a few days after the tributary streams had higher than normal streamflows. The decrease in water clarity during these periods suggests that the water quality of the reservoir is closely related to the water quality of the tributary streams.

\section{Chemical Constituents}

Water samples were collected and analyzed for nutrients, organic carbon, major ions, alkalinity, silica, and pesticides to further evaluate the water quality of Breckenridge Reservoir. The following sections include discussions related to the analytical results of these water samples and how they compare to other reservoirs in the region.

\section{Nutrients}

Water samples collected from Breckenridge Reservoir were analyzed for the species of nitrogen commonly present in water- nitrite, nitrate, ammonia, and organic nitrogen (app. 7). Dissolved nitrite-nitrogen concentrations in samples collected from the reservoir were at or below the laboratory minimum reporting level (MRL) of $0.002 \mathrm{mg} / \mathrm{L}$. Dissolved nitrite-plus-nitrate nitrogen and dissolved ammonia-nitrogen concentrations ranged from less than the MRLs of 0.016 and $0.01 \mathrm{mg} / \mathrm{L}$, respectively, to 0.043 and $0.08 \mathrm{mg} / \mathrm{L}$, respectively. Total nitrogen (the sum of the nitrogen species) concentrations ranged from 0.11 to $0.54 \mathrm{mg} / \mathrm{L}$. Nutrient concentrations in samples that were collected near the bottom of the reservoir were similar to those in samples collected near the surface (table 5).

The mean nitrite-plus-nitrate concentration determined for samples collected at 1.0-ft depth at all the three reservoir sites $(0.020 \mathrm{mg} / \mathrm{L})$ was lower than the mean nitrite-plus-nitrate concentration determined for samples collected from Lunga Reservoir (0.026 mg/L; Lotspeich, 2007). The mean nitriteplus-nitrate concentration determined for samples from the Pea Hill Arm of Lake Gaston Reservoir was also higher at $0.066 \mathrm{mg} / \mathrm{L}$ (Woodside, 1994). Water samples collected from the Chickahominy, Diascund, and Little Creek Reservoirs all had mean nitrite-plus-nitrate nitrogen concentrations that were $<0.1 \mathrm{mg} / \mathrm{L}$ (Lynch, 1992).

The mean total nitrogen concentration determined for water samples collected at $1.0-\mathrm{ft}$ depth of $0.33 \mathrm{mg} / \mathrm{L}$ in Breckenridge Reservoir, was less than the mean total nitrogen concentrations determined for other reservoirs in the region. By comparison, the mean total nitrogen concentrations determined for Lunga, Chickahominy, Diascund Creek, Little Creek, and Pea Hill Arm of Lake Gaston reservoirs were 0.4, 0.8, 0.7, 0.7, and $0.5 \mathrm{mg} / \mathrm{L}$, respectively (Lynch, 1992; Woodside, 1994; Lotspeich, 2007).

The mean dissolved ammonia-nitrogen concentration determined for water samples collected at 1.0-ft depth in Breckenridge Reservoir was of $0.04 \mathrm{mg} / \mathrm{L}$. By comparison, the Lunga, Pea Hill Arm of Lake Gaston, Chickahominy, Diascund Creek, and Little Creek reservoirs had mean dissolved ammonia-nitrogen concentrations of 0.04, 0.40, $0.80,0.60$, and $0.65 \mathrm{mg} / \mathrm{L}$, respectively (Lynch, 1992 ; Woodside, 1994; Lotspeich, 2007).

Water samples collected from the three Breckenridge Reservoir sampling sites were analyzed for total phosphorus, dissolved phosphorus, and dissolved orthophosphorus concentrations. Total phosphorus concentrations determined for samples collected from the reservoir at $1.0-\mathrm{ft}$ depth ranged from 0.013 to $0.041 \mathrm{mg} / \mathrm{L}$, whereas concentrations of dissolved phosphorus ranged from 0.005 to $0.016 \mathrm{mg} / \mathrm{L}$. Dissolved orthophosphorus concentrations in samples collected at 1.0-ft depth and near the bottom in Breckenridge Reservoir were below the MRL of $0.008 \mathrm{mg} / \mathrm{L}$. The maximum total phosphorus concentration from samples collected in the reservoir was $0.041 \mathrm{mg} / \mathrm{L}$, slightly above the SWCB criteria of 40 micrograms per liter $(\mu \mathrm{g} / \mathrm{L})$, or $0.040 \mathrm{mg} / \mathrm{L}$ (Commonwealth of Virginia State Water Control Board, 2011). The mean total phosphorus concentration in Breckenridge Reservoir, $0.022 \mathrm{mg} / \mathrm{L}$, is near the average of the mean concentrations determined for the Lunga, Chickahominy, Diascund Creek, and Little Creek Reservoirs, which were $0.016,0.049,0.028$, and $0.014 \mathrm{mg} / \mathrm{L}$, respectively (Lynch, 1992; Lotspeich, 2007). 
Table 5. Nutrient concentrations at various depths at sampling sites in Breckenridge Reservoir, Virginia, December 17, 2008, and August 25, 2009.

[Concentrations in milligrams per liter; ${ }^{\mathrm{E}}$, estimated concentration; $\mathrm{ft}$, feet; <, less than]

\begin{tabular}{|c|c|c|c|c|c|c|c|c|c|c|c|c|}
\hline \multirow{4}{*}{ Constituent } & \multicolumn{6}{|c|}{ December 17, 2008} & \multicolumn{6}{|c|}{ August 25, 2009} \\
\hline & \multicolumn{2}{|c|}{ Site 01659700} & \multicolumn{2}{|c|}{ Site 01660020} & \multicolumn{2}{|c|}{ Site 01660030} & \multicolumn{2}{|c|}{ Site 01659700} & \multicolumn{2}{|c|}{ Site 01660020} & \multicolumn{2}{|c|}{ Site 01660030} \\
\hline & \multicolumn{6}{|c|}{ Sampled depth (ft) } & \multicolumn{6}{|c|}{ Sampled depth (ft) } \\
\hline & 1.0 & 8.0 & 1.0 & 23.0 & 1.0 & 29.0 & 1.0 & 8.0 & 1.0 & 22.0 & 1.0 & 30.0 \\
\hline Dissolved nitrite-nitrogen & $0.001^{\mathrm{E}}$ & $0.001^{\mathrm{E}}$ & $0.002^{\mathrm{E}}$ & $0.002^{\mathrm{E}}$ & $0.002^{\mathrm{E}}$ & $0.002^{\mathrm{E}}$ & $<0.002$ & $<0.002$ & $<0.002$ & $<0.002$ & $<0.002$ & $<0.002$ \\
\hline Dissolved nitrite-plus-nitrate & 0.017 & 0.018 & 0.041 & 0.033 & 0.043 & 0.038 & $<0.016$ & $<0.016$ & $0.011^{\mathrm{E}}$ & $0.010^{\mathrm{E}}$ & $0.014^{\mathrm{E}}$ & $0.010^{\mathrm{E}}$ \\
\hline Dissolved ammonia-nitrogen & $0.015^{\mathrm{E}}$ & $0.014^{\mathrm{E}}$ & $0.014^{\mathrm{E}}$ & 0.021 & $0.017^{\mathrm{E}}$ & 0.025 & 0.026 & $0.015^{\mathrm{E}}$ & 0.048 & 0.099 & 0.064 & 0.089 \\
\hline Total dissolved nitrogen & 0.47 & 1.39 & 0.53 & 0.93 & 0.31 & 1.26 & 0.38 & 0.34 & 0.36 & 0.40 & 0.37 & 0.35 \\
\hline Total nitrogen & 0.25 & 0.34 & 0.35 & 0.32 & 0.33 & 0.36 & 0.33 & 0.34 & 0.34 & 0.39 & 0.36 & 0.42 \\
\hline Dissolved orthophosphorus & $<0.008$ & $<0.008$ & $<0.008$ & $<0.008$ & 0.004 & $<0.008$ & $<0.008$ & $<0.008$ & $<0.008$ & $<0.008$ & $<0.008$ & $<0.008$ \\
\hline Total dissolved phosphorus & 0.013 & 0.009 & 0.008 & 0.009 & 0.008 & 0.009 & 0.010 & 0.010 & 0.011 & 0.011 & 0.010 & 0.011 \\
\hline Total phosphorus & 0.024 & 0.033 & 0.027 & 0.031 & 0.028 & 0.032 & 0.021 & 0.025 & 0.020 & 0.024 & 0.021 & 0.025 \\
\hline
\end{tabular}

\section{Organic Carbon}

Concentrations of total organic carbon (TOC) in samples collected at $1.0-\mathrm{ft}$ depth in the reservoir ranged from 2.3 to $9.8 \mathrm{mg} / \mathrm{L}$ (app. 7). The mean TOC concentration of $5.61 \mathrm{mg} / \mathrm{L}$ is between the mean TOC concentrations in the Pea Hill Arm of Lake Gaston and Chickahominy reservoirs, which were 5.2 and $9.5 \mathrm{mg} / \mathrm{L}$, respectively (Lynch, 1992; Woodside, 1994), and very similar to the mean TOC concentration of $5.82 \mathrm{mg} / \mathrm{L}$ in Lunga Reservoir (Lotspeich, 2007). Concentrations of TOC in the Diascund Creek and Little Creek reservoirs were not measured and, as a result could not be compared to the results from Breckenridge Reservoir samples.

Concentrations of dissolved organic carbon (DOC) determined for samples collected at 1.0-ft depth in Breckenridge Reservoir ranged from 2.1 to $9.7 \mathrm{mg} / \mathrm{L}$, with a mean concentration of $5.01 \mathrm{mg} / \mathrm{L}$ (app. 7). The mean DOC concentration from Breckenridge Reservoir samples was higher than the mean DOC concentration of $4.38 \mathrm{mg} / \mathrm{L}$ determined for Lunga Reservoir (Lotspeich, 2007).

\section{Major lons}

Concentrations of the major cations (calcium, magnesium, potassium, and sodium) and major anions (chloride, fluoride, and sulfate) in water samples collected from Breckenridge Reservoir generally were low, varied seasonally, and varied little spatially (app. 8). Concentrations of cations and anions in the reservoir samples also did not vary when comparing the 1.0-ft depth samples with the near bottom samples (table 6).
The SWCB lists maximum allowable concentrations of chloride, fluoride, and sulfate for public water supply. The maximum dissolved chloride concentration in the reservoir samples, $4.44 \mathrm{mg} / \mathrm{L}$ (4,440 $\mu \mathrm{g} / \mathrm{L}$, app. 8), was below the SWCB criterion of $250,000 \mu \mathrm{g} / \mathrm{L}(250 \mathrm{mg} / \mathrm{L})$ for chloride concentrations in the public water supply, but higher than the maximum dissolved chloride concentration of $2.98 \mathrm{mg} / \mathrm{L}$ in Lunga Reservoir (Lotspeich, 2007). The maximum dissolved fluoride concentration in the reservoir samples, $0.09 \mathrm{mg} / \mathrm{L}$ (90 $\mu \mathrm{g} / \mathrm{L}$, app. 8), was below the SWCB criterion of $1,100 \mu \mathrm{g} / \mathrm{L}(1.1 \mathrm{mg} / \mathrm{L})$ for fluoride concentrations in public water supply and slightly lower than the maximum dissolved sulfate concentration of $0.10 \mathrm{mg} / \mathrm{L}$ in Lunga Reservoir (Lotspeich, 2007). The maximum dissolved sulfate concentration in the reservoir samples, $4.00 \mathrm{mg} / \mathrm{L}$ $(4,000 \mu \mathrm{g} / \mathrm{L}$, app. 8$)$, was below the SWCB criterion of $250,000 \mu \mathrm{g} / \mathrm{L}(250 \mathrm{mg} / \mathrm{L})$ for sulfate concentrations in the public water supply and lower than the maximum dissolved sulfate concentration of $4.54 \mathrm{mg} / \mathrm{L}$ in Lunga Reservoir (Lotspeich, 2007).

Although the SWCB has no criteria for the other major ions analyzed during this study, mean concentrations of the other dissolved major ions in Breckenridge Reservoir samples were similar to or less than those determined for the Lunga, Chickahominy, Diascund Creek, and Little Creek Reservoirs (Lynch, 1992; Lotspeich, 2007; table 7). 
Table 6. Mean dissolved major-ion concentrations at 1-foot depth at sampling sites in Breckenridge Reservoir, Virginia, during September 2008 through August 2009, compared to other reservoirs.

[Concentrations in milligrams per liter; $<$, less than]

\begin{tabular}{|c|c|c|c|c|c|}
\hline Constituent & $\begin{array}{c}\text { Breckenridge } \\
\text { Reservoir }\end{array}$ & $\begin{array}{c}\text { Lunga } \\
\text { Reservoir }{ }^{1}\end{array}$ & $\begin{array}{c}\text { Chickahominy } \\
\text { Reservoir }^{2}\end{array}$ & $\begin{array}{l}\text { Diascund } \\
\text { Creek } \\
\text { Reservoir }^{2}\end{array}$ & $\begin{array}{l}\text { Little Creek } \\
\text { Reservoir }^{2}\end{array}$ \\
\hline Calcium & 2.63 & 1.68 & 7.1 & 10 & 9.5 \\
\hline Chloride & 3.23 & 2.57 & 18 & 6.4 & 11 \\
\hline Fluoride & 0.05 & 0.08 & $<0.1$ & $<0.1$ & $<0.1$ \\
\hline Magnesium & 1.42 & 1.06 & 1.9 & 0.89 & 1.6 \\
\hline Potassium & 1.22 & 0.90 & 1.6 & 1.1 & 1.7 \\
\hline Sodium & 3.27 & 2.45 & 12 & 3.2 & 6.8 \\
\hline Sulfate & 3.26 & 3.72 & 9.6 & 6.6 & 9.0 \\
\hline
\end{tabular}

${ }^{1}$ From Lotspeich, 2007.

${ }^{2}$ From Lynch, 1992.

Table 7. Dissolved major-ion concentrations at various depths at sampling sites in Breckenridge Reservoir, Virginia, December 17, 2008, and August 25, 2009.

[Concentrations in milligrams per liter; $\mathrm{ft}$, feet; - , no data]

\begin{tabular}{|c|c|c|c|c|c|c|c|c|c|c|c|c|}
\hline \multirow{4}{*}{ Constituent } & \multicolumn{6}{|c|}{ December 17, 2008} & \multicolumn{6}{|c|}{ August 25, 2009} \\
\hline & \multicolumn{2}{|c|}{ Site 01659700} & \multicolumn{2}{|c|}{ Site 01660020} & \multicolumn{2}{|c|}{ Site 01660030} & \multicolumn{2}{|c|}{ Site 01659700} & \multicolumn{2}{|c|}{ Site 01660020} & \multicolumn{2}{|c|}{ Site 01660030} \\
\hline & \multicolumn{6}{|c|}{ Sampled depth (ft) } & \multicolumn{6}{|c|}{ Sampled depth (ft) } \\
\hline & 1.0 & 8.0 & 1.0 & 23.0 & 1.0 & 29.0 & 1.0 & 8.0 & 1.0 & 22.0 & 1.0 & 30.0 \\
\hline Alkalinity & 9 & 9 & 9 & - & 8 & 9 & 15 & 14 & 14 & 15 & 14 & 15 \\
\hline Calcium & 2.19 & 2.21 & 2.24 & 2.25 & 2.32 & 2.32 & 3.10 & 3.02 & 3.08 & 3.04 & 3.05 & 2.98 \\
\hline Chloride & 3.34 & 3.32 & 3.18 & 3.20 & 3.15 & 3.07 & 2.97 & 3.00 & 2.96 & 2.97 & 2.97 & 2.95 \\
\hline Fluoride & 0.04 & 0.04 & 0.04 & 0.04 & 0.04 & 0.05 & 0.07 & 0.05 & 0.05 & 0.05 & 0.05 & 0.05 \\
\hline Magnesium & 1.31 & 1.30 & 1.34 & 1.31 & 1.28 & 1.27 & 1.59 & 1.55 & 1.57 & 1.54 & 1.56 & 1.53 \\
\hline Potassium & 1.31 & 1.35 & 1.47 & 1.52 & 1.51 & 1.52 & 0.90 & 0.81 & 0.95 & 1.00 & 1.00 & 1.01 \\
\hline Silica & 13.3 & 13.5 & 11.9 & 11.7 & 11.2 & 11.5 & 9.41 & 9.44 & 9.51 & 9.87 & 9.56 & 9.83 \\
\hline Sodium & 3.34 & 3.27 & 3.22 & 3.14 & 3.08 & 2.99 & 3.21 & 3.23 & 3.19 & 3.15 & 3.12 & 3.12 \\
\hline Sulfate & 3.84 & 3.84 & 3.78 & 3.90 & 3.71 & 3.65 & 2.33 & 2.36 & 2.67 & 2.41 & 2.46 & 2.62 \\
\hline
\end{tabular}




\section{Alkalinity}

Alkalinity is the ability of a solution to neutralize acids and buffer changes in $\mathrm{pH}$. Alkalinity concentrations determined from water samples collected in Breckenridge Reservoir ranged from 4 to $15 \mathrm{mg} / \mathrm{L}$ as calcium carbonate $\left(\mathrm{CaCO}_{3}\right)$ (app. 6). These concentrations were similar to those determined in samples collected from Lunga Reservoir which ranged from 3.3 to $13.9 \mathrm{mg} / \mathrm{L}$ as $\mathrm{CaCO}_{3}$ (Lotspeich, 2007). Alkalinity values varied little among the three reservoir sampling sites. The mean alkalinity concentration determined for samples collected from Breckenridge Reservoir during the study was $11.3 \mathrm{mg} / \mathrm{L}$ as $\mathrm{CaCO}_{3}$. By comparison, the mean alkalinity concentrations determined for the Chickahominy, Diascund Creek, and Little Creek Reservoirs were 18, 22, and $24 \mathrm{mg} / \mathrm{L}$ as $\mathrm{CaCO}_{3}$, respectively (Lynch, 1992), and was $6.3 \mathrm{mg} / \mathrm{L}$ as $\mathrm{CaCO}_{3}$ for Lunga Reservoir (Lotspeich, 2007).

\section{Silica}

Silica $\left(\mathrm{SiO}_{2}\right)$ usually is present in moderately abundant concentrations in freshwater lakes and reservoirs, ranging from 5 to $25 \mathrm{mg} / \mathrm{L}$ (Langmuir, 1997). Silicon (Si) is an element that influences algal production in many reservoirs, because diatoms (a type of algae) use silica in developing their skeletons, or frustules. This use of silica in the life cycle of diatoms can greatly reduce dissolved silica concentrations in surface waters. As a result, silica concentrations in lakes and reservoirs typically vary both spatially and seasonally.

Dissolved silica concentrations in samples collected from Breckenridge Reservoir ranged from 7.5 to $15.4 \mathrm{mg} / \mathrm{L}$ (app. 8). The mean dissolved silica concentration determined for the reservoir samples was $11.4 \mathrm{mg} / \mathrm{L}$. By comparison, the mean dissolved silica concentrations determined for the Chickahominy, Diascund Creek, and Little Creek Reservoirs were 5.1, 3.6, and $1.8 \mathrm{mg} / \mathrm{L}$, respectively (Lynch, 1992), and $7.53 \mathrm{mg} / \mathrm{L}$ for the Lunga Reservoir (Lotspeich, 2007).

\section{Pesticides}

Water samples were collected and analyzed for pesticide concentrations in Breckenridge Reservoir to evaluate potential contamination resulting from the use of pesticides throughout the watershed. Samples were collected twice during the study at all three of the reservoir sampling locations. Samples were analyzed for 53 pesticides (app. 2) and only atrazine was found above the laboratory MRL of $0.007 \mu \mathrm{g} / \mathrm{L}$.

Atrazine is a widely used agricultural pesticide that has become increasingly controversial due to human-health concerns related to its presence in drinking-water supplies. Under the Safe Drinking Water Act, the U.S. Environmental Protection Agency has determined that no more than 3 parts per billion (ppb) of atrazine (as a running annual average) can be present in drinking water (National Resources Defense Council, 2011). Atrazine concentrations were $0.008 \mu \mathrm{g} / \mathrm{L}$
$(0.008 \mathrm{ppb})$ near the surface and $0.010 \mu \mathrm{g} / \mathrm{L}(0.010 \mathrm{ppb})$ near the bottom at all three sampling sites. At the time of this publication, the SWCB has not listed an established criterion for atrazine concentrations.

\section{Biological Constituents}

Water samples collected from Breckenridge Reservoir were analyzed for Escherichia coliform (E. coli) bacteria because it is an indicator of fecal contamination from warmblooded animals. E. coli counts generally were low, ranging from 1 to 130 colonies per $100 \mathrm{~mL}$ (col/100 mL) (app. 6) of sample. None of the E. coli counts exceeded the SWCB water-supply standard of $126 \mathrm{col} / 100 \mathrm{~mL}$, which is based on a geometric mean of two or more samples collected during any calendar month (Commonwealth of Virginia State Water Control Board, 2011). The maximum monthly geometric, three-sample mean E. coli colony count for Breckenridge Reservoir was $109 \mathrm{col} / 100 \mathrm{~mL}$ in May 2009. The second highest monthly geometric, three-sample mean $E$. coli colony count was $82 \mathrm{col} / 100 \mathrm{~mL}$ in December 2008 (fig. 10).

Elevated bacteriological counts coincided with higher than-normal flow events in the tributary streams. For example, the reservoir sampling site located above South Branch Chopawamsic Creek had the highest $E$. coli colony count only once during the study, whereas the sampling site below South Branch Chopawamsic Creek had the highest count five times, as did the site at the dam. This suggests that the water quality of Breckenridge Reservoir is very closely related to the water quality in the tributary streams and that South Branch Chopawamsic Creek is the greatest source of E. coli bacteria to the reservoir.

\section{Trophic Status}

The trophic status of a reservoir is an indicator of its physical, chemical, and biological condition and is typically classified into one of four categories - oligotrophic, mesotrophic, eutrophic, or hypereutrophic. Lakes or reservoirs that can be categorized as oligotrophic have the most pristine conditions and those that are categorized as hypereutrophic have the poorest conditions. As a reservoir ages, its trophic condition evolves from oligotrophic to hypereutrophic. This evolution is natural but can be accelerated by human activities.

The trophic state index (TSI) is a method used to classify the trophic status of a reservoir and can be computed using near-surface total phosphorus concentrations (Carlson, 1977). TSI values based on total phosphorus concentrations (TSIP) for a reservoir are computed using the following equation:

$$
T S I P=14.42 \ln (T P)+4.15
$$

where

$T P=$ total phosphorus concentrations, in micrograms per liter. 


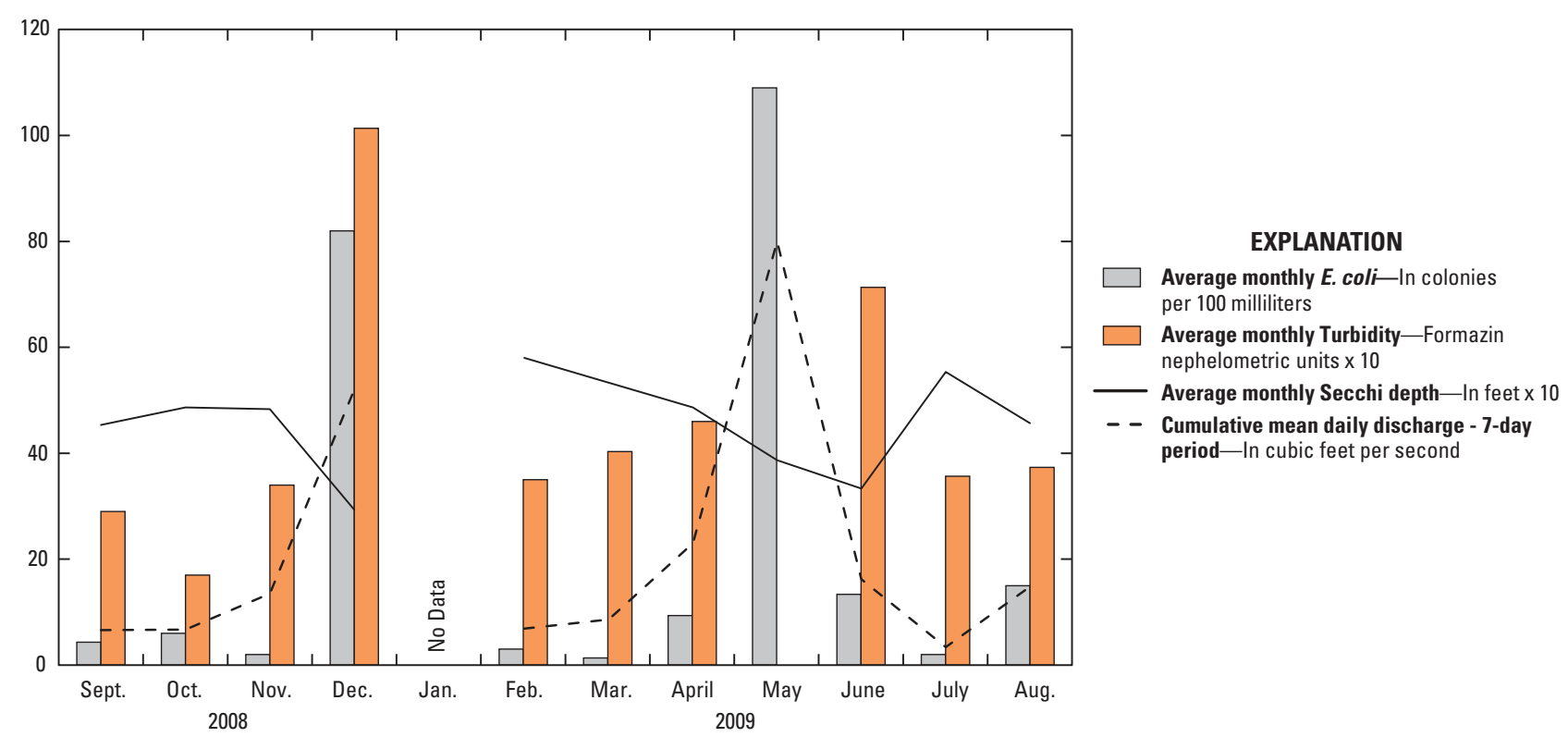

Figure 10. Monthly mean E. coli counts, turbidity measurements, and Secchi-disk depths, and cumulative mean daily discharges in tributary streams for sampling periods in Breckenridge Reservoir, Virginia.

Trophic state classifications based on the Carlson (1977) TSI are oligotrophic (0-30), mesotrophic (31-50), eutrophic (51-69), and hypereutrophic (greater than (>) 69). The TSIP ranged from mesotrophic to eutrophic for all sites sampled in Breckenridge Reservoir. Surface TSIP values for all sampling sites in the reservoir indicated that the reservoir was generally mesotrophic with some fluctuation between mesotrophic and eutrophic during the summer. TSIP values for the samples that were pumped from near the bottom of the reservoir indicated generally eutrophic conditions.

\section{Bottom-Material Quality}

Bottom-material samples were collected on July 7, 2009, at all three sampling sites in the reservoir. These samples were analyzed for the following trace elements: arsenic, cadmium, chromium, cobalt, copper, iron, lead, manganese, mercury, nickel, phosphorus, selenium, and zinc. Concentrations of trace elements in the bottom material increased from the upper to the lower parts of the reservoir with samples from the upper site having the lowest concentrations (except cadmium) and the spillway site having the highest concentrations (table 8; fig. 1).

The SWCB currently has no criteria for concentrations of trace elements in bottom material in lakes and reservoirs. However, bottom material samples collected from Lunga Reservoir in 2004 were analyzed for many of the same trace elements (Lotspeich, 2007) as were analyzed in Breckenridge Reservoir bottom samples. Concentrations of most trace elements in bottom-material samples collected from Breckenridge Reservoir were higher than those in samples from Lunga Reservoir (table 9). Concentrations of trace elements such as iron and lead in bottom samples from Breckenridge Reservoir were 3 and 12 times higher, respectively, than concentrations in bottom samples collected from Lunga Reservoir. Bottom-material samples were not collected at the three tributary sites to determine if these relatively high trace-element concentrations were present upstream from the reservoir.

\section{Water Quality of Tributary Sites}

Water-quality samples were collected and physical properties were measured at three stream sites, one located on each of the tributaries to Breckenridge Reservoir (fig. 1, sites 4-6; apps. 9-11). North Branch Chopawamsic Creek was sampled monthly, because it was part of another ongoing water-quality project for the USMC Quantico. Middle Branch and South Branch Chopawamsic Creeks were sampled five times-November 2008, and February, March, May, and August 2009. The USGS operated gaging stations on each of these tributary streams; therefore, streamflow data were available for each of these sites during the study.

Streamflow and selected water-quality indicators suggest a close relationship between Breckenridge Reservoir and its tributaries (fig. 10). The average monthly E. coli count, turbidity, and Secchi-disk depth determined for the three reservoir sites occurred very closely in time with increased streamflow in the tributaries. The maximum mean daily discharge was totaled for all three tributary streams in the 7 days prior to collection of reservoir samples, and this cumulative discharge total was plotted, as shown in figure 10. 
Table 8. Concentrations of trace elements in bottom-material samples from Breckenridge Reservoir, Virginia, July 7, 2009.

[Site locations shown in figure 1. Concentrations are in micrograms per gram, except where noted. $\mathrm{mg} / \mathrm{kg}$, milligrams per kilogram]

\begin{tabular}{|c|c|c|c|c|c|c|c|c|c|c|c|c|c|}
\hline Arsenic & $\begin{array}{l}\text { Cad- } \\
\text { mium }\end{array}$ & $\begin{array}{l}\text { Chro- } \\
\text { mium }\end{array}$ & Cobalt & Copper & Iron & Lead & $\begin{array}{c}\text { Manga- } \\
\text { nese }\end{array}$ & Mercury & Nickel & $\begin{array}{l}\text { Phos- } \\
\text { phorus } \\
\text { (mg/kg) }\end{array}$ & $\begin{array}{l}\text { Sele- } \\
\text { nium }\end{array}$ & Zinc & $\begin{array}{c}\text { Moisture } \\
\text { content } \\
\text { (percenage) }\end{array}$ \\
\hline \multicolumn{14}{|c|}{ Breckenridge Reservoir above South Branch Chopawamsic Creek near Joplin (site 3) } \\
\hline 2.9 & 0.26 & 47.7 & 20.5 & 22.6 & 29,000 & 28 & 490 & 0.02 & 27.3 & 280 & 0.6 & 90.3 & 65 \\
\hline \multicolumn{14}{|c|}{ Breckenridge Reservoir below South Branch Chopawamsic Creek near Joplin (site 2) } \\
\hline 4.0 & 0.22 & 55.4 & 25.8 & 47.9 & 47,000 & 190 & 880 & 0.04 & 30.6 & 74 & 0.7 & 106 & 73 \\
\hline \multicolumn{14}{|c|}{ Breckenridge Reservoir at Dam near Joplin (site 1) } \\
\hline 6.7 & 0.34 & 79.9 & 61.4 & 73.2 & 76,000 & 380 & 1,400 & 0.06 & 43.2 & 800 & 1.0 & 152 & 86 \\
\hline
\end{tabular}

Table 9. Mean trace-element concentrations in bottom material from Breckenridge and Lunga Reservoirs, Virginia

[Concentrations are in micrograms per gram, except as noted. $\mathrm{mg} / \mathrm{kg}$, milligrams per kilogram; <, less than]

\begin{tabular}{lcc}
\hline \multicolumn{1}{c}{ Constituent } & $\begin{array}{c}\text { Breckenridge } \\
\text { Reservoir }\end{array}$ & $\begin{array}{c}\text { Lunga } \\
\text { Reservoir }\end{array}$ \\
\hline Arsenic & 4.53 & 1.44 \\
Cadmium & 0.27 & 0.24 \\
Chromium & 61.0 & 11.7 \\
Copper & 48.0 & 11.0 \\
Iron & 50,700 & 17,400 \\
Lead & 199 & 16.4 \\
Manganese & 923 & 432 \\
Mercury & 0.04 & 0.06 \\
Nickel & 33.7 & 9.17 \\
Phosphorus $(\mathrm{mg} / \mathrm{kg})$ & 385 & 502 \\
Selenium & 1.0 & $<1.0$ \\
Zinc & 116 & 41.2 \\
\hline
\end{tabular}

${ }^{1}$ From Lotspeich, 2007. 
During the course of the study, increased turbidity and E. coli bacteria counts were observed during or after periods of increased tributary discharge, whereas Secchi-disk depths decreased during those same periods.

Although no turbidity value was recorded in May 2009, the bacteriological samples collected that month yielded the highest average monthly $E$. coli colony count $(109 \mathrm{col} / 100 \mathrm{~mL})$ for Breckenridge Reservoir. Just one day prior to this sampling event, the cumulative mean daily discharge for the tributaries was the highest for the study period, 80 cubic feet per second $\left(\mathrm{ft}^{3} / \mathrm{s}\right)$. The second highest cumulative mean daily discharge in the tributaries, $52 \mathrm{ft}^{3} / \mathrm{s}$, occurred in December 2008 during the same period as the second highest E. coli count, $82 \mathrm{col} / 100 \mathrm{~mL}$, and the highest recorded average turbidity value, 10.1 FNU. Conversely, the lowest average Secchi-disk depths occurred in December 2008 and May 2009, indicating a decrease in water clarity in the days immediately following periods of increased tributary streamflow.

\section{Summary}

Water samples were collected and physical properties were measured by the U.S. Geological Survey at three sites in Breckenridge Reservoir, and physical properties were measured at six additional reservoir sites from September 2008 through August 2009. Water samples were also collected and physical properties were measured in each of the three major tributaries to Breckenridge Reservoir: North Branch Chopawamsic Creek, Middle Branch Chopawamsic Creek, and South Branch Chopawamsic Creek. One site on each tributary was sampled five times during the study.

The analytical results of reservoir and tributary samples collected and physical properties measured during this study were compared to ambient water-quality standards of the Virginia Department of Environmental Quality and Virginia State Water Control Board (SWCB). In general, the waterquality of Breckenridge Reservoir is similar to other reservoirs in the region, and the measurements made during this study indicate the reservoir is healthy and is not in violation of published SWCB ambient water-quality standards.

Monthly profiles were conducted for water temperature, dissolved-oxygen concentrations, specific conductance, $\mathrm{pH}$, and turbidity measured at 2-ft-depth intervals throughout the water column of the reservoir. These profiles were conducted at nine sites in the reservoir, and data values were measured at these sites from the water surface to the bottom of the reservoir. These profiles were conducted along three cross sections and were used to define the characteristics of the entire water column of the reservoir.

During the study period, water temperatures measured throughout the water column at the nine Breckenridge Reservoir sites ranged from 3.2 to $27.7^{\circ} \mathrm{C}$, below the SWCB maximum water temperature ambient water-quality criteria of $32^{\circ} \mathrm{C}$. Dissolved-oxygen concentrations measured in the reservoir ranged from 2.8 to $11.7 \mathrm{mg} / \mathrm{L}$, and fell below the SWCB minimum dissolved-oxygen ambient water-quality criterion of $4.0 \mathrm{mg} / \mathrm{L}$ at the surface of the reservoir at two sites in September 2008. Specific conductance values measured throughout the water column in the reservoir ranged from 36 to $99 \mu \mathrm{S} / \mathrm{cm}$, with a mean specific conductance of $52 \mu \mathrm{S} / \mathrm{cm}$. Measurements of $\mathrm{pH}$ made throughout the water column of the reservoir ranged from 5.6 to 8.7 standard units, which fell within the SWCB pH ambient water-quality criterion of 6.0 to 9.0 standard units, except for September 2008.

Water samples collected from Breckenridge Reservoir were analyzed for the species of nitrogen commonly present in water - nitrite, nitrate, ammonia, and organic nitrogen. Dissolved nitrite-nitrogen concentrations in samples collected from the reservoir were at or below the minimum reporting level of $0.002 \mathrm{mg} / \mathrm{L}$. Dissolved nitrite-plus-nitrate nitrogen and dissolved ammonia-nitrogen concentrations ranged from less than the minimum reporting levels of 0.016 and $0.01 \mathrm{mg} / \mathrm{L}$, respectively, to 0.043 and $0.08 \mathrm{mg} / \mathrm{L}$, respectively. Total nitrogen (the sum of the nitrogen species) concentrations ranged from 0.11 to $0.54 \mathrm{mg} / \mathrm{L}$. Nutrient concentrations in samples that were collected near the bottom of the reservoir were similar to those in samples collected near the surface.

Concentrations of the major cations (calcium, magnesium, potassium, and sodium) and major anions (chloride, fluoride, and sulfate) in water samples collected from Breckenridge Reservoir generally were low, varied seasonally, and varied little spatially. Concentrations of cations and anions in the reservoir samples also did not vary when comparing the 1.0-ft depth samples with the near bottom samples. Concentrations of total organic carbon in samples collected at 1.0-ft depth in the reservoir ranged from 2.3 to $9.8 \mathrm{mg} / \mathrm{L}$, and concentrations of DOC dissolved organic carbon ranged from 2.1 to $9.7 \mathrm{mg} / \mathrm{L}$.

Water samples were analyzed for 53 pesticides, and only atrazine was found to be above the laboratory minimum reporting level. Atrazine concentrations of 0.008 and 0.010 microgram per liter were found near the surface and bottom, respectively, at all three sampling locations. At the time of this publication, the Virginia State Water Control Board has not listed an established criterion for concentrations of atrazine.

Bottom material samples were collected for analysis of trace elements at all three reservoir sampling sites. Concentrations of arsenic, cadmium, and mercury in bottom material were similar to those analyzed in other reservoirs in the region. However, most other constituents that were collected from Breckenridge Reservoir, especially iron and lead, showed much higher concentrations than in the other reservoirs.

Streamflow and select water-quality indicators suggest a close relationship between Breckenridge Reservoir and its tributaries. During the course of the study, increased turbidity and E. coli bacteria counts were observed during or after periods of increased tributary discharge, while Secchi-disk depths decreased during those same periods. These streamflow and water-quality indicators suggest a close relationship between Breckenridge Reservoir and its tributaries. 


\section{Selected References}

Carlson, R.E., 1977, A trophic state index for lakes: Limnology and Oceanography, v. 22, p. 361-369.

Commonwealth of Virginia State Water Control Board, 2011, 9 VAC 25-260 - Virginia Water Quality Standards: 143 p., accessed May 2011 at http://www.deq.virginia.gov/ wqs/documents/WQS_eff_6JAN2011.pdf

Goetz, S.J., Jantz, C.A., Prince, S.D., Smith, A.J., Varlyguin, D., and Wright, R., (2004), Integrated analysis of ecosystem interactions with land use change: The Chesapeake Bay watershed, in DeFries, R.S., Asner, G.P., and Houghton, R.A., eds., Ecosystems and land use change: Washington D.C., American Geophysical Union, Geophysical Monograph Series, 275 p.

Langmuir, D., 1997, Aqueous environmental geochemistry: Englewood Cliffs, N.J., Prentice-Hall, 600 p.

Lotspeich, R.R., 2007, The quality of water and bottom material in Lunga Reservoir, Virginia, September 2004 through August 2005: U.S. Geological Survey Open-File Report 2007-1053, 52 p.

Lynch, D.D., 1992, Water quality and evaluation of raw-waterrouting scenarios, Chickahominy, Diascund Creek, and Little Creek Reservoirs, southeastern Virginia, 1983-86: U.S. Geological Survey Water-Resources Investigations Report 92-4034, 104 p.
Myers, D.N., and Wilde, F.D., eds., 2003, Biological indicators (3d ed.): U.S. Geological Survey Techniques of Water-Resources Investigations, book 9, chap. A7, accessed September 2004 at http://pubs.water.usgs.gov/twri9A7/.

National Resources Defense Council, 2011, Atrazine: Poisoning the well-Atrazine in public water systems and watersheds: Website, accessed August 2011 at $h t t p: / / w w w$. nrdc.org/health/atrazine/.

Wetzel, R.G., 2001, Limnology, lake and river ecosystems (3d ed.): San Diego, Calif., Academic Press, 1,006 p.

Wilde, F.D., Radtke, D.B., Gibs, Jacob, and Iwatsubo, R.T., eds., 1999, Collection of water samples: U.S. Geological Survey Techniques of Water-Resources Investigations, book 9, chap. A4, accessed September 2004 at http://pubs.water.usgs.gov/twri9A4/.

Woodside, M.D., 1994, Land use in, and water quality of, the Pea Hill Arm of Lake Gaston, Virginia and North Carolina, 1988-90: U.S. Geological Survey Water-Resources Investigations Report 94-4140, $54 \mathrm{p}$. 


\section{Appendixes}

Appendix 1. Laboratory reporting levels for major ions and nutrients analyzed in water samples collected from Breckenridge Reservoir, Virginia, September 2008 through August 2009.

Appendix 2. Laboratory reporting levels for pesticides analyzed in water samples collected from Breckenridge Reservoir, Virginia, September 2008 through August 2009.

Appendix 3. Summary of physical properties at various depths for Breckenridge Reservoir above Dam near Joplin, Virginia (01660030) and cross-section profiling points.

Appendix 4. Summary of physical properties at various depths for Breckenridge Reservoir below South Branch Chopawamsic Creek near Joplin, Virginia (01660020), and cross-section profiling points (fig. 1, site 2).

Appendix 5. Summary of physical properties at various depths for Breckenridge Reservoir above South Branch Chopawamsic Creek near Joplin, Virginia (01659700), and cross-section profiling points.

Appendix 6. Summary of various constituents at 1-foot depth at sampling sites in Breckenridge Reservoir, Virginia.

Appendix 7. Summary of nutrient concentrations at 1-foot depth at sampling sites in Breckenridge Reservoir, Virginia.

Appendix 8. Summary of dissolved major-ion concentrations at 1-foot depth at sampling sites in Breckenridge Reservoir, Virginia.

Appendix 9. Summary of water quality samples at North Branch Chopawamsic Creek near Independent Hill, Virginia.

Appendix 10. Summary of water quality samples at Middle Branch Chopawamsic Creek near Garrisonville, Virginia.

Appendix 11. Summary of water quality samples at South Branch Chopawamsic Creek near Garrisonville, Virginia.

Note: Appendixes—Downloadable Excel and Word files are available online. 


\section{Prepared by}

U.S. Geological Survey

Science Publishing Network

Raleigh Publishing Service Center

3916 Sunset Ridge Road

Ralieigh, NC 27607

A PDF version of this publication is available online at http://pubs.usgs.gov/of/2011/1305/ 
